\title{
REGIÃO, DESIGUALDADES REGIONAIS E DESENVOLVIMENTO SUSTENTÁVEL
}

Carlos Eduardo Mazzeto

Heloísa S. Moura Costa

Maria Luiza Grossi

Ralfo Matos

Samy Kopit

\section{Resumo}

A partir da análise dos processos de organização espacial, discute-se o conceito de região, suas implicações, abrangências e novas abordagens requeridas para o entendimento das formas e funções desencadeadoreas de mecanismos estruturadores, desestruturadores e/ou reestruturadores de determinados espaços regionais. Discute-se o desenvolvimento regional, tomando-se como referencial básico alguns pressupostos acerca da definição de desigualdade regional e desenvolvimento sustentável. Isto se faz mediante a utilização do conceito de região, categoria geográfica apropriada à internalização da diversidade de tipos de "desenvolvimento" e, especificamente, do desenvolvimento sustentável regional. Nesta perspectiva, busca-se a reconstituição da trajetória da utilização das categorias teóricas propostas por estudiosos e apresentadas na literatura especializada. Finalmente, verifica-se a necessidade da introdução de concepções contemporâneas relacionadas ao desenvolvimento, inserindo no debate algumas das suas novas tendências, principalmente no que diz respeito à sustentabilidade e ao desenvolvimento local-regional.

Palavras chaves: Desenvolvimento regional; Desenvolvimento sustentável; Desigualdade regional; Geografia econômica 


\section{1- INTRODUÇÃO}

O mundo atual convive com intensas e profundas mudanças na reordenação dos fluxos de capital e na reestruturação produtiva, fazendo emergir mercados ou blocos econômicos, em meio a uma intensa manipulação da informação financeira. Nesse contexto, as organizações governamentais ainda desempenham um papel decisivo, não obstante a crise que perpassa os Estados há vários anos, impondo-lhes transformações em profundidade. A tríade, fluxos de capital financeiro, formação de novos mercados e informação, estrutura a ideia de mundialização do capital financeiro, como uma espécie de suposto para uma (pós) modernidade. Por meio da mundialização das trocas, expressa-se a universalização do consumo, instaurando novas racionalidades e modos de vida, nos quais se supervalorizam a técnica e a tecnologia. Espaços de fixação são criados e recriados: novos distritos indústrias, programas e pacotes agropecuários, espaços urbanos globalizados, entre outros.

O conceito de região assume novos contornos no processo de organização espacial, sinalizando para o ordenamento de "inéditas" formas e funções desencadeadoras de mecanismos estruturadores, desestruturadores e/ou reestruturadores de certos espaços regionais. Na mesma direção, grafam-se e/ou acentuam-se, novas e antigas desigualdades regionais. Pergunta-se: como esse fenômeno tem influenciado os processos de

desenvolvimento regional? É possível apontar para um desenvolvimento urbano e rural/agrícola nesse espaço geográfico, tendo em vista formas mais duradouras de prosperidade?

Para uma aproximação com a problematização enunciada, é objetivo desse texto, promover uma breve discussão sobre o desenvolvimento regional, tomando como referência alguns dos supostos do que seja a desigualdade regional e o desenvolvimento sustentável. Parte-se da premissa, bastante razoável, de se entender a região como categoria geográfica apropriada à internalização da diversidade da noção de desenvolvimento 
regional e, por conseguinte, do desenvolvimento sustentável regional. $\mathrm{Na}$ mesma perspectiva, o texto busca reconstituir a trajetória formal de utilização desse conceito, assim como enfatizar algumas tentativas de sistematização encontradas na literatura especializada, o que coloca a necessidade de se introduzir algumas concepções do que seja desenvolvimento.

\section{2 - NOÇÕES ACERCA DA DESIGUALDADE REGIONAL}

O estudo da desigualdade regional, há várias décadas, tem sido objeto de análise, entre numerosos pesquisadores (Myrdal, Isard, Hirschman, Santos, Oliveira, entre outros). Dentre as contribuições expressas por esses autores, destacar-se-ão algumas ideias que soam oportunas para enquadrar a discussão atual sobre desenvolvimento e desigualdades regionais, enfatizando a pluralidade analítica que o tema requer.

Frequentemente, a desigualdade regional é apontada como sendo o resultado de diferenciais econômicos e sociais inter-regionais, decorrentes das distintas capacidades das regiões de atrair mais ou menos investimentos. Tais evidências refletir-se-iam nas dinâmicas internas regionais, aludindo ao processo de formação das desigualdades regionais. Por outro lado, a mensuração da desigualdade regional também envolve indicadores sociais e/ou de bem-estar social. Alguns autores estabelecem distinção entre desigualdade regional e diferenciação espacial/regional, sustentando que a desigualdade regional é antes a materialização de processos históricos no espaço. Há aqueles autores que defendem a noção de estrutura espacial/regional para explicar as desigualdades regionais, enquanto outros indicam a necessária conexão entre desigualdades regionais e desigualdade social, aporte imprescindível à compreensão de região como expressão territorial de uma formação social.

HIERNAUX \& LINDÓN (1997) destacam a ação do capitalismo nos territórios regionais. Nos anos 70, difundiu-se a tese de que o desenvolvimento do capitalismo agiria como elemento de homogeneização das estruturas econômicas regionais (OLIVEIRA, Cadernos do Leste

Artigos Cientificos

Belo Horizonte, Edição Especial, 2000 a 2008 
1977), à medida que funcionasse como difusor das relações de mercado e de produção, minimizando diferenças espaciais. Assim, o uso dos espaços geográficos seria mediado pelas tendências homogeneizadoras impostas pelo avanço do capitalismo. Contrariamente, uma outra corrente apontava para a existência do capitalismo como causa maior das desigualdades regionais, uma vez que acentuava a divisão territorial do trabalho, exigindo formas de especialização dos ecossistemas e, portanto, disseminando o uso diferencial do território, o que seria uma maneira de acentuar as desigualdades regionais (SEJENOVICH, 1978). Uma terceira ideia acerca da relação do capitalismo com o desenvolvimento regional indicava que, para uma região desenvolver-se, seria necessário a mobilização de seus recursos naturais em resposta às demandas advindas de mercados externos (nacionais e/ou internacionais). Nesse caso, o crescimento regional seria produzido pela convergência de oferta de recursos naturais e demandas externas, aproveitando-se da existência de "vantagens comparativas", de modo que a produção fosse realizada com custos menores que em outros espaços regionais. Afirmam os defensores desta tese (PERLOFF \& WINGO, 1964): só há desigualdade regional porque há insuficiência de recursos naturais que não respondem àquelas demandas externas, ou, porque há uma apropriação indevida na forma de aproveitamento dos recursos.

Para ROFMAN (1984), entretanto, as análises da maioria dos estudos regionais deixam de contemplar os processos socioeconômicos e políticos que atuam nas regiões. Argumenta que uma análise consequente de regionalização deve perguntar sobre quais processos mudam na articulação entre as regiões e quais estruturas materiais permanecem. Devem-se reconhecer as atividades dominantes em torno das quais os processos de acumulação regional ocorrem. A estes aspectos somam-se as formas técnicas e de produção, de caráter familiar ou empresarial/patronal, pelas quais se organizam as atividades produtivas. Para o autor, são estes "específicos marcos espaciais", os elos produtivos que implicam organização espacial. A identificação desses elos, permite reconhecer a diversidade de circuitos produtivos, no que denominou "circuito econômico 
de acumulação regional.” A partir do reconhecimento dos agentes sociais e de suas formas de ação, as desigualdades regionais podem ser explicadas pela "geração, apropriação desigual e utilização do excedente produzido.” (ROFMAN, 1984)

Nas últimas décadas, a discussão política e teórico conceitual sobre a questão do desenvolvimento ganhou mais densidade, sobretudo após a crescente generalização da idéia de desenvolvimento sustentável.

\section{3 - DAS NOÇÕES DE DESENVOlVIMENTO ATÉ O CONCEITO DE DESENVOLVIMENTO SUSTENTÁVEL}

Ao se resgatar dos dicionários o significado das palavras desenvolver e desenvolvimento, verifica-se, que desenvolver é "fazer com que progrida, aumente, melhore, se adiante". O desenvolvimento é tido como "ato ou efeito de desenvolver-se. [...]. Estágio econômico, social, político de uma comunidade caracterizado por altos índices de rendimento dos fatores de produção, os recursos naturais, o capital e o trabalho.”(FERREIRA, 1975. p. 452 - 453).

Tomado, isoladamente, o sentido da palavra 'desenvolver' assume uma parcialidade, uma praticidade, remetendo às ideias de progresso, de melhora ou adiantamento. Por sua vez, desenvolvimento envolve uma representação econômica, social e política, explicitada na caracterização dos índices de rendimentos conjugados com os fatores de produção, recursos naturais, capital e trabalho de uma comunidade. Prenuncia-se, aqui, o ato relacional que o desenvolvimento é em si. Etimologicamente, desenvolvimento tem origem no prefixo des (desfazer) e envolvimento (envolver). Desenvolver uma região é desdobrar, é desenrolar, é desfazer o que não é envolvimento.

Paradoxalmente, o desenvolvimento com frequência é posto (imposto) na sociedade ocidental como categoria instituinte da modernidade, "qualidade ou caráter de Cadernos do Leste 
moderno.” (FERREIRA, 1975. p. 934), na qual, a diversidade é substituída por um “consenso" de adaptações nos usos ou necessidades "modernas". As transformações das condições de existência dos lugares regionais, como princípio do desenvolvimento modernizador, têm sugerido novos processos de organização da produção e do modo de vida regional.

Nessa concepção, para se atingir um estágio de desenvolvimento urbano e/ou rural, seria imperiosa a intervenção do Estado. O conteúdo político é, então, colocado como articulador da base desenvolvimentista inscrita, na concepção e entendimento do que venha a ser o desenvolvimento. Nestes termos, tal conteúdo reporta-se à vontade dos diferentes atores políticos de "transformar" sua sociedade.

É evidente que o projeto da modernidade desenvolvimentista e seus significados nunca deixaram de ter críticos severos. BERNSTEIN, (1975) apud HARVEY (1989, p. 25), conclama a análise feita por Max Weber a esse respeito:

"... a esperança e expectativa dos pensadores iluministas era uma amarga e irônica ilusão. Eles mantinham um forte vínculo necessário entre o desenvolvimento da ciência, da racionalidade e da liberdade humana universal. Mas, quando desmascarado e compreendido, o legado do Iluminismo foi o triunfo da racionalidade [...] proposital-instrumental. [...] O desenvolvimento da [racionalidade proposital-instrumental] não leva à realização concreta da liberdade universal, mas à criação de uma "jaula de ferro" da racionalidade burocrática da qual não há como escapar."

A noção de progresso aí embutida, encontra adeptos na representação espacial dos ideais do Estado. O planejamento (rural-urbano e/ou regional) como elemento estratégico de previsibilidade promovido pelo Estado, encontra na organização espacial, a aplicação das teses do crescimento e do desenvolvimento. As técnicas aplicadas pelo planejamento são, portanto, apontadas como "elementos de um processo do conhecimento humano organizado e especializado no sistema capitalista e que atuam num espaço econômico territorializado.” (GERTEL, 1994, p.108). 
Para SANTOS (1988), esse processo pode ser balizado por três fenômenos, a saber: a unicidade da técnica, a unicidade do tempo e a unicidade do que move este processo. Isto quer dizer que, historicamente, tem-se promovido, por meio do Estado, um modelo de desenvolvimento tecnológico que estabelece a redução de incertezas, seja no âmbito sóciofactual, seja no que se refere à dinâmica econômica propriamente dita. Há, portanto, evidências, em numerosos territórios e regiões, da simultaneidade da ação dos processos tecnológicos, sem, no entanto, ter em conta os processos que prefiguram a diversidade local- regional. A dimensão espacial e temporal dos processos e fenômenos geográficos passa a ser transgredida pela racionalidade técnica, geralmente, avalizada pela ação estatal.

De fato, a modernidade, no seu próprio significado etimológico (atualidade, o que é de hoje), confunde-se com a contemporaneidade:

"Representa uma ânsia e uma inevitabilidade. A opção não estaria em ser ou não moderno mas em o que é ser moderno (qual retrato do futuro desejado pela sociedade) e o como ser moderno (quais as intenções, prioridades, medidas e instrumentos a serem usados na construção desse futuro).” (BUARQUE, 1994, p. 14)

Nesse contexto, não se pode deixar de apontar a incisiva preocupação em relação ao meio ambiente: de um lado, pela tradição filosófica prometeica, como controle técnico da natureza e de seus recursos tendo em vista o bem e a emancipação humana, "em particular, das classes mais numerosas e pobres” (na formulação Saint-Simoniana); de outro, pela tradição fáustica, procura-se "desmascarar os argumentos prometeicos, e ultrapassar [...] o niilismo tecnológico, condição pela qual a técnica não serve a qualquer objetivo humano para além da sua própria expressão.”(MARTINS, 1997, p. 290)

Portanto, no processo de organização territorial-regional, o nexo da técnica, com a modernidade/modernização/desenvolvimento exige a necessária discussão em torno dos resultados práticos dessa ordenação. Da compressão tecnológica incidente sobre a realidade espacial, aponta-se para a resultante envolvendo uma natureza cuja estrutura ambiental 
encontra-se fraturada em sua sustentação: crescente custo ambiental do desenvolvimento industrial do pós-guerra; superprodução agrícola aliada ao esgotamento dos solos e erosão, comprometimento das nascentes e cursos d'água (além da má distribuição de alimentos); eclosão de movimentos sociais urbanos e rurais. Dessa forma, impõe-se o debate e ação "para compreender o ajustamento dos níveis espaciais significativos referidos às diferentes escalas e a análise destes diferentes níveis." de desenvolvimento regional.(LÉVY apud GERTEL, 1994, p.112)

Vários autores, ao traçarem as origens do conceito de desenvolvimento sustentável, enfatizam sua utilização a partir de meados da década de oitenta, associando-o a uma importante mudança de enfoque na definição da problemática ambiental, qual seja, a passagem de enfoques considerados conservacionistas, prevalecentes no início dos anos setenta, para aqueles que buscam associar desenvolvimento econômico à preservação ambiental. Isto haveria de acarretar importantes implicações em termos de formulação de políticas e propostas de intervenção.

Há, porém, uma mudança radical nas concepções tradicionais das relações homemnatureza, atribuída por muitos autores ao conjunto de rupturas pela modernidade, que antecede e contextualiza a emergência do conceito de desenvolvimento sustentável. Tal mudança será discutida a seguir.

\section{1 - A relação homem-natureza e os paradigmas dominantes no pensamento e na ciência moderna}

A emergência da questão ambiental e do movimento ambientalista, a partir das décadas de 70 e 80 , é marcada por uma forte reação ao antropocentrismo, historicamente dominante.

Cadernos do Leste

Artigos Cientificos

Belo Horizonte, Edição Especial, 2000 a 2008 
A separação, efetivada pelo pensamento moderno, entre homem e natureza, fez com que, a partir do século XVIII até a época contemporânea, o homem - separado da natureza - fosse o ator e sujeito central (senão exclusivo) do universo. A natureza é tida como algo a ser dominado, controlado, explorado e posto a serviço do progresso humano.

As origens desta concepção de mundo são descritas por CAPRA (1982, p. 49):

"A visão do mundo e os sistemas de valores que estão na base de nossa cultura, e que tem de ser cuidadosamente reexaminados, foram formulados em suas linhas essenciais nos séculos XVI e XVII. Entre 1500 e 1700 houve uma mudança drástica na maneira como as pessoas descreviam o mundo e em todo o seu modo de pensar. A nova mentalidade e a nova percepção do cosmo, propiciaram à nossa civilização ocidental aqueles aspectos que são característicos da era moderna. Eles tornaram-se a base do paradigma que dominou a nossa cultura nos últimos trezentos anos...”

Ainda segundo o autor, "a noção de um universo orgânico, vivo e espiritual, foi substituída pela noção do mundo como se ele fosse uma máquina, e a máquina do mundo converteu-se na metáfora dominante da era moderna.” (CAPRA, 1982, p. 49)

Mais à frente, Capra se refere ao papel de Francis Bacon (1561-1626), no estabelecimento das formas modernas de relação homem/natureza: "A partir de Bacon, o objetivo da ciência passou a ser aquele conhecimento que pode ser usado para dominar e controlar a natureza e, hoje, ciência e tecnologia buscam sobretudo fins profundamente antiecológicos." (CAPRA, 1982, p. 51)

Citando ainda expressões de Francis Bacon que refletem esta postura frente à natureza que deve ser “...acossada em seus descaminhos [...] obrigada a servir... e ...escravizada." Devia ser "reduzida à obediência", e o objetivo do cientista era "extrair da natureza, sob tortura, todos os seus segredos.” (BACON apud CAPRA, 1982, p. 52)

CAPRA conclui o raciocínio afirmando que:

Cadernos do Leste

Artigos Cientificos

Belo Horizonte, Edição Especial, 2000 a 2008 
"O antigo conceito de Terra como mãe nutriente foi radicalmente transformado nos escritos de Bacon e desapareceu por completo quando a revolução científica tratou de substituir a concepção orgânica da natureza pela metáfora do mundo como máquina. Essa mudança, viria a ser de suprema importância para o desenvolvimento subsequente da civilização ocidental, foi iniciada e completada por duas figuras gigantescas do século XVII: Descartes e Newton." (CAPRA, 1982, p. 52)

Também SANTOS se refere a esta faceta do pensamento e da ciência moderna.

Afirma no seu livro Um discurso sobre as ciências:

"Por outro lado, é total a separação entre a natureza e ser humano. A natureza é tão-só extensão e movimento; é passiva, eterna e reversível, mecanismo cujos elementos se podem desmontar e depois relacionar sob a forma de leis; não tem qualquer outra qualidade ou dignidade que nos impeça de desvendar os seus mistérios, desvendamento que não é contemplativo, mas antes ativo, já que visa conhecer a natureza para a dominar e controlar. Como diz Bacon, a ciência fará da pessoa humana "o senhor e o possuidor da natureza." (SANTOS, 1987, p. 13)

Esta visão separatista entre homem e natureza traz sérias ambiguidades como aponta GONÇALVES (1989, p. 26-27):

“... a expressão dominar a natureza só tem sentido a partir da premissa de que o homem é não-natureza... Mas se o homem é também natureza, como falar em dominar a natureza? Teríamos que falar em dominar o homem também... E aqui a contradição fica evidente. Afinal, quem dominaria o homem? Outro homem? Isso só seria concebível se aceitássemos a ideia de um homem superior, de uma raça superior, pura - e a História já demonstrou à farta as consequências destas concepções.

A natureza é, em nossa sociedade, um objeto a ser dominado por um sujeito, o homem, muito embora saibamos que nem todos os homens são proprietários da natureza. Assim, são alguns poucos homens que dela verdadeiramente se apropriam. A grande maioria dos outros homens não passa, ela também, de objeto que pode até ser descartado."

É a partir de René Descartes (1596-1650), que essa nova forma de pensar o mundo ganhou consistência científica no método analítico por ele desenvolvido. A busca da verdade primeira e a preocupação fundamental em evitar o erro, são o seu ponto de partida. Convertendo a dúvida em método (ARANHA, 1986), prioriza o sujeito sobre o objeto e 
valoriza, quase mitificando, a razão: "cogito ergo sun". Baseado no racionalismo matemático, Descartes irá influenciar toda a ciência da Idade Moderna.

Mais tarde, Auguste Comte (1789-1857) consolida suas ideias num método científico ao qual denominou de positivismo. Embasado na certeza rigorosa dos fatos da experiência como fundamento da construção teórica (JÚNIOR, 1991), este método evita indagar a essência das coisas, despreza a inacessível determinação das causas, dando preferência à procura de leis, isto é, das relações constantes que existem entre os fenômenos. O método encontra seu desenvolvimento, principalmente, nas ciências naturais e acaba se caracterizando como uma filosofia determinista que professa, de um lado, o experimentalismo sistemático e, de outro, considera anticientífico todo o estudo das causas finais. Delimita, assim, o campo da ciência a um certo patamar de análise dos fatos e fenômenos da vida e do mundo, excluindo do campo científico várias de suas questões fundamentais, sobre as quais qualquer impressão ou afirmação deve ser vista como mera divagação anticientífica. Ou seja, o método tem maior peso na definição do que é ciência, e até onde ela pode ir, do que a realidade, a sociedade, a vida, o mundo e suas múltiplas dimensões combinadas. (SILVA, 1996a)

Ao método positivista se uniu o pensamento iluminista (luz da razão), com suas ideias de progresso, de emancipação humana, enriquecimento da vida diária, domínio científico da natureza, libertação da escassez, das calamidades naturais, das irracionalidades do mito, da religião, da superstição e do uso arbitrário do poder. O Iluminismo sintetiza o projeto da modernidade, procurando revelar as qualidades universais, eternas e imutáveis de toda humanidade, prometendo progresso e bem-estar. Ele pressupõe a existência de uma única resposta possível a qualquer pergunta, o que possibilita o controle e a organização do mundo de modo racional, desde que se consiga apreendê-lo de modo correto. (HARVEY, 1993)

Cadernos do Leste

Artigos Cientificos

Belo Horizonte, Edição Especial, 2000 a 2008 
A quebra da hegemonia da Igreja Católica ocorrida com a Reforma Anglicana, a revolução na percepção de mundo provocada pelo heliocentrismo, o racionalismo de Descartes e o empirismo baconiano marcam o início de uma visão laicizada do mundo. A natureza, dessacralizada, torna-se fonte do progresso humano, matéria-prima, objeto, em contraposição ao homem-sujeito. É criada uma oposição entre sociedade/cultura e natureza. A civilização não existe sem o seu controle. Mais tarde, a Revolução Industrial e a urbanização reforçariam o afastamento progressivo da natureza. O capitalismo vem consolidar uma relação utilitária com os "recursos naturais" - reduzidos À matéria-prima básica para o processamento, transformação em mercadoria e geração de lucro, que por sua vez amplia as condições de exploração destes recursos.

"A ideia de uma natureza objetiva e exterior ao homem, o que pressupõe uma ideia de homem não-natural e fora da natureza, cristaliza-se com a civilização industrial inaugurada pelo capitalismo. As ciências da natureza se separam das ciências do homem; cria-se um abismo colossal entre uma e outra..." (GONÇALVES, 1989, p. 35)

As características do pensamento iluminista e da ciência moderna (positivismo, racionalismo matemático) consolidam-se como um paradigma dominante, e estabelecem, definitivamente, sérias contradições com a problemática ambiental que vai ascender nos anos 60. A título de síntese, podemos alinhar os seguintes valores filosóficos e científicos modernos que estarão no centro destas contradições:

Método científico e matemático, reducionista, cindindo sujeito e objeto e, por consequência, homem/natureza, espírito/matéria, fragmentando a realidade e os objetos de estudo, provocando uma forte compartimentalização disciplinar;

Pensamento e visão antropocentrista e utilitarista, com ênfase no domínio e controle da natureza a fim de servir aos interesses humanos;

Fé inabalável no progresso técnico;

Cadernos do Leste

Artigos Cientificos

Belo Horizonte, Edição Especial, 2000 a 2008 
Ideias, discursos e soluções universalizantes e homogeneizadoras. (SILVA, 1996b)

Esses valores, forjados em especial no desenvolvimento da civilização européia (a mesma que vai levantar inicialmente a problemática ambiental), difundiram-se e expandiram-se por todo o ocidente, e seguem, hoje, em direção ao Oriente. É em reação a estes valores (ou pelo menos a parte deles), que se levanta o movimento ambientalista.

\section{2 - A história recente da discussão da questão ambiental}

$\mathrm{Na}$ literatura recente, a referência mais antiga à questão ambiental é feita por Barbier (1987), ao atribuir sua origem ao ano de 1968, quando da realização das Conferências sobre a Biosfera em Paris e sobre Aspectos Ecológicos do Desenvolvimento Internacional em Washington. Assim, a célebre Conferência das Nações Unidas sobre o (Meio) Ambiente Humano, ocorrida em Estocolmo em 1972, e considerada um marco na discussão ambiental ao nível internacional, teria tido, principalmente, o mérito de popularizar o conceito. Naquele momento, a posição majoritária frente à discussão que se iniciava, enfatizava a necessidade de se estabelecer mecanismos de proteção ambiental para correção de problemas decorrentes do desenvolvimento econômico, e reverter a intensidade do crescimento demográfico com vistas a se atingir uma população estável. (VIOLA \& LEIS, 1992)

Portanto, o debate atual da sustentabilidade ou do desenvolvimento sustentável, é herdeiro de situações históricas que deflagaram a temática ambiental a partir dos anos 60, as quais geraram, posteriormente, a chamada "onda ecológica". Assim, surgiam vários movimentos que questionavam a ordem estabelecida pela sociedade tecnológica-industrial de consumo (GONÇALVES, 1989), e ganhava dimensão a questão ambiental. Segundo DIEGUES (1996, p.39):

“o novo ecologismo surgiu com as agitações estudantis de 1968, nos Estados Unidos e na Europa. As questões ecológicas passaram a ser uma das bandeiras de luta, Cadernos do Leste Artigos Cientificos 
ao lado do anti-militarismo/pacifismo, direitos das minorias, etc. Como afirma Simonnet (1979), maio de 1968 foi um sobressalto na história e um movimento pela vida "contra o mundo senil e triste."

É neste contexto que foi publicado o relatório da Comissão Mundial sobre o Meio Ambiente e Desenvolvimento, Nosso Futuro Comum, - popularmente cunhado de Relatório Brundtland (1987) - que vai disseminar, definitivamente, o conceito de desenvolvimento sustentável.

VIOLA \& LEIS (1992, p. 77) afirmam que:

“a favorável acolhida ao Relatório Brundtland dá ao conceito de desenvolvimento sustentável um reconhecimento que o conceito de ecodesenvolvimento nunca teve, mas outorgou-lhe também um caráter polissêmico, em função da atração simultânea de economistas, planificadores em desenvolvimento, agências internacionais, acadêmicos, ambientalistas, ONGs, políticos e público em geral."

Afinal, não há como ser contra uma ideia de sustentação para o desenvolvimento. A insustentabilidade pode ser algo que, afinal, ameace e afete a todos.

Entretanto, para estes autores, o amplo espectro das significações deste conceito, tende a fortalecê-lo politicamente (não obstante suas contradições), muitas vezes á custa do enfraquecimento de seus conteúdos científicos - se é que é possível o enquadramento científico do termo.

A ideia básica, contida no Relatório Brundtland, refere-se ao ideal de harmonizar o desenvolvimento econômico com a proteção ambiental:

"O desenvolvimento sustentável é aquele que atende às necessidades do presente sem comprometer a possibilidade de as gerações futuras atenderem a suas próprias necessidades. Ele contém dois conceitos-chave:

- o conceito de necessidades essenciais dos pobres do mundo, que devem receber a máxima prioridade;

- a noção das limitações que o estágio da tecnologia e da organização social impõe ao meio ambiente, impedindo-o de atender às necessidades presentes e futuras." (CMMAD, 1988, p. 46) 
Para Bruseke, o relatório apresenta uma lista de medidas a serem tomadas pelos governos nacionais. A saber:

“a) limitação do crescimento populacional; b) garantia da alimentação a longo prazo; c) preservação da biodiversidade e dos ecossistemas; d) diminuição do consumo de energia e desenvolvimento de tecnologias que admitem o uso de fontes energéticas renováveis; e) aumento da produção industrial nos países não-industrializados à base de tecnologias ecologicamente adaptadas; f) controle da urbanização selvagem e integração entre campo e cidades menores; g) as necessidades básicas devem ser satisfeitas." (BRUSEKE, 1995, p. 33)

Neste momento, alguns aspectos importantes da discussão conceitual e política merecem ser destacados, inclusive, porque vão determinar linhas diferenciadas de abordagem do tema. Seguem-se algumas delas.

\section{i) As relações norte-sul e a necessidade de um novo enfoque analítico para o desenvolvimento econômico sustentável}

Dando ênfase particular às relações norte-sul, BARBIER (1987) observa que o conceito de desenvolvimento econômico vem sofrendo mudanças ao longo do tempo. Atualmente, envolve: a resolução das necessidades básicas dos pobres, aspectos sócioculturais e a participação popular no processo de desenvolvimento. Além disto, para haver "desenvolvimento real" as metas relativas ao meio ambiente e ao desenvolvimento devem ser as mesmas ou, pelo menos, não estar em conflito. Dito de outra forma, as estratégias a serem formuladas devem ser ambientalmente sustentáveis A curto e a longo prazo.

Partindo de uma definição convencional presente no pensamento não-marxista contemporâneo, segundo a qual desenvolvimento econômico é o "processo pelo qual a renda "per capita" real de um país aumenta por um longo período, desde que o número de pessoas abaixo da linha de pobreza absoluta não aumente e que a distribuição de renda não se torne mais desigual, BARBIER (1987) contrapõe a noção de desenvolvimento econômico sustentável. Nela a preocupação básica deve ser a garantia de que a população pobre tenha acesso a uma existência sustentável e segura. Seu objetivo principal é, então,

Cadernos do Leste

Artigos Cientificos

Belo Horizonte, Edição Especial, 2000 a 2008 
reduzir a pobreza absoluta por meio da provisão de condições de vida seguras e duradouras, que minimizem a degradação dos recursos materiais e do meio ambiente, a desestruturação cultural e a instabilidade social.

Assim, em contraste com o desenvolvimento econômico convencional, para o autor citado, o desenvolvimento sustentável é indissociável do desenvolvimento global da sociedade, pois depende de mudanças econômicas, sociais, culturais e ecológicas. Também, por contraposição, não é facilmente mensurável, já que suas dimensões quantitativa e qualitativa se misturam: a primeira estaria associada à melhoria das condições de vida da população vivendo em situações de pobreza absoluta, enquanto que a dimensão qualitativa é multifacetada, estando associada ao potencial ecológico, social e cultural para dar suporte tanto às atividades econômicas quanto às mudanças estruturais.

Ao enfatizar as questões relativas à resolução das necessidades básicas da população, em particular dos mais pobres, Barbier estabelece um importante avanço em relação às definições anteriores, não se registrando distinção entre os níveis de produção, consumo ou bem-estar dos diversos grupos sociais ou sociedades/países. Ao buscar redefinir o conceito, aplicando-o à realidade dos países do terceiro mundo, o autor evita cair na armadilha malthusiana que atribui ao excesso populacional o ônus do nãodesenvolvimento ou da degradação ambiental. Entretanto, ainda assim, a pobreza comparece como uma espécie de causa (ou grande agravante) da degradação ambiental, fazendo com que análise se ressinta de uma ligação mais explícita com os condicionantes e limitações inerentes ao funcionamento do capitalismo, particularmente na periferia. De qualquer forma, duas ideias são fundamentais em seu trabalho: a primeira é que não há sustentabilidade possível com pobreza e a segunda reforça as múltiplas dimensões (para além da puramente econômica) do desenvolvimento sustentável.

No âmbito de suas propostas, BARBIER (1987) advoga a necessidade de um novo enfoque analítico para a abordagem do desenvolvimento econômico sustentável, mediante 
a interação de metas de três sistemas: um biológico, um econômico e um social $^{1}$. Ao procurar maximizar as metas dos três sistemas, o desenvolvimento econômico sustentável envolve um processo de "trade off" entre elas, dada a impossibilidade de que sejam obtidas todas de uma só vez.

É importante ressaltar que parte desta discussão, principalmente no que se refere ao desenvolvimento econômico, não é nova, correspondendo a um avanço ou a uma redescoberta do intenso debate desenvolvimentista dos anos cinquenta e sessenta. Segundo COSTA (1994, p. 56), o desenvolvimento sustentável "veio para suprir o vácuo deixado pela Economia do Desenvolvimento", sendo, inclusive, em virtude das contradições que são inerentes àquele conceito, um substituto "teoricamente mais vulnerável e, para a formulação de políticas de desenvolvimento, muito mais precário que o original" ${ }^{2}$. No caso específico da América Latina, alguns autores fazem uma interessante discussão crítica do conceito, a partir das experiências históricas do continente, buscando identificar as razões pelas quais o desenvolvimento latino-americano, em geral, não leva em conta critérios de sustentabilidade ${ }^{3}$.

\section{ii) Sachs: as múltiplas dimensões da sustentabilidade e as estratégias de transição para o próximo século}

Partindo de um outro enfoque analítico, também SACHS (1993) mostrou a importância das múltiplas dimensões do desenvolvimento sustentável, bem como as

\footnotetext{
${ }^{1}$ As metas inerentes ao sistema biológico seriam: diversidade genética, resiliência e produtividade biológica; as metas do sistema econômico seriam: satisfação das necessidades básicas, equidade e aumento de bens e serviços úteis; já as metas do sistema social seriam: diversidade cultural, sustentabilidade institucional, justiça social e participação da população. A título de exemplo da utilização deste esquema, o autor menciona a tradição marxista, que buscaria maximizar as metas dos sistemas econômico e social, sem a preocupação com o sistema ecológico.

${ }^{2}$ Cabe ressaltar aqui uma interessante distinção que este autor explicita entre desenvolvimento sustentável e desenvolvimento auto-sustentado, que corresponderia então a um "processo simultâneo de aumento continuado da renda e de transformações quantitativas e qualitativas sócio-estruturais que persiste por tempo relativamente longo, revigorado por determinantes de geração endógena garantidores da manutenção desse dinamismo." (COSTA, 1994, p.51)

${ }^{3}$ Ver, coletânea organizada por GOODMAN \& REDCLIF (1991) para o caso da América Latina em geral. GONÇALVES (1995), numa outra perspectiva, discute algumas características importantes da questão ambiental no caso específico do Brasil.
}

Cadernos do Leste

Artigos Cientificos

Belo Horizonte, Edição Especial, 2000 a 2008 
diferenças Norte-Sul. Entretanto, diferentemente de Barbier, ele vai se concentrar principalmente no processo e nas estratégias de transição para se chegar ao desenvolvimento sustentável, pois, "a verdadeira escolha não é entre desenvolvimento e meio ambiente, mas entre formas de desenvolvimento sensíveis ao meio ambiente e formas insensíveis ao mesmo." (SACHS, 1993, p. 31)

Segundo o autor, todo planejamento de desenvolvimento precisa levar em conta, de forma simultânea, cinco dimensões de sustentabilidade, quais sejam:

Sustentabilidade social - visa maior equidade na distribuição de bens e renda, reduzindo a diferença entre padrões de vida de ricos e pobres;

Sustentabilidade econômica - visa eficiência econômica, avaliada em termos macrossociais, pressupondo alocação e gerenciamento eficiente de recursos, além de constantes investimentos públicos e privados;

Sustentabilidade ecológica - por meio de um conjunto de medidas como redução do consumo de recursos não -renováveis, diminuição do volume de resíduos e de poluição, aumento da capacidade de carga da Terra, definição de normas de proteção ambiental, intensificação de pesquisa de novas tecnologias, etc;

Sustentabilidade espacial - visa a obtenção de uma configuração ruralurbana mais equilibrada e melhor distribuição territorial dos assentamentos humanos e das atividades econômicas ${ }^{4}$;

Sustentabilidade cultural - visa mudanças baseadas na continuidade cultural, de raízes endógenas, com soluções específicas para o local, o ecossistema, a cultura e o território. (SACHS, 1993)

\footnotetext{
${ }^{4}$ A este respeito, SACHS (1993) dedica especial atenção ao que intitula de enfrentamento da "explosão urbana", quando alinha algumas estratégias de eco desenvolvimento urbano, visando considerar as cidades como ecossistemas, ou seja, como fontes potenciais de recursos a serem utilizados de forma adequada.

Cadernos do Leste

Artigos Cientificos

Belo Horizonte, Edição Especial, 2000 a 2008
} 
Apesar de seu caráter normativo, definindo estratégias a serem seguidas pelos diferentes blocos de países, o autor enfatiza a importância dos compromissos específicos a serem implementados por cada país em função de suas características particulares. Ainda assim, ressalta a necessidade de ações de caráter global, o que coloca em discussão a controvertida premência de uma gestão ambiental que transcenda os limites e competências dos Estados Nacionais. A implementação de tais ações seria, então, de responsabilidade do sistema Nações Unidas. As dificuldades nas negociações de tratados internacionais, acordos multilaterais, ou até mesmo cartas-síntese de Conferências Internacionais, a exemplo do Habitat II, entre outras, evidenciam que esta não é, de forma alguma, uma questão trivial:

“O eco desenvolvimento é um estilo de desenvolvimento que, em cada ecorregião, insiste nas soluções específicas de seus problemas particulares, levando em conta os dados ecológicos da mesma forma que os culturais, as necessidades imediatas como também aquelas a longo prazo. Opera, portanto, com critérios de progresso relativizados a cada caso, aí desempenhando papel importante a adaptação ao meio postulada pelos antropólogos. Sem negar a importância dos intercâmbios, o eco desenvolvimento tenta reagir à moda predominante das soluções pretensamente universalistas e das fórmulas generalizadas. Em vez de atribuir um espaço excessivo à ajuda externa, dá um voto de confiança à capacidade das sociedades humanas de identificar os seus problemas e de lhes dar soluções originais, ainda que se inspirando em experiências alheias. Reagindo contra as transferências passivas e o espírito de imitação, põe em destaque a autoconfiança. resistindo a um ecologismo exagerado, sugere, ao contrário a constante possibilidade de um esforço criador para o aproveitamento da margem de liberdade oferecida pelo meio, por maiores que sejam as restrições climáticas e naturais. A diversidade das culturas e das realizações humanas obtidas em meios naturais comparáveis são testemunhos eloquentes desta possibilidade. Mas o sucesso pressupõe o conhecimento do meio e a vontade de atingir um equilíbrio durável entre o homem e a natureza.” (SACHS,1986, p.18) 
As estratégias de transição formuladas baseiam-se nas seguintes premissas: a) devem cobrir um período de várias décadas; b) cabe aos países industrializados assumir a maior fatia dos custos de transição e do ajuste tecnológico; c) dependem da ousadia das mudanças institucionais, da habilidade de se projetar pacotes de políticas multidimensionais e da capacidade de se redirecionar o progresso tecnológico; e d) devem modular a demanda por meio de mudanças nos estilos de vida, padrões de consumo e funções de produção, por meio da incorporação de técnicas ambientalmente adequadas e fazendo as escolhas locacionais corretas.

Em que pese à justeza das estratégias formuladas, podem ser apontados elementos de quase ingenuidade na proposta, uma vez que os condicionantes de natureza estrutural passam para um plano secundário. Por outro lado, o pragmatismo presente sob a forma de estratégias de ação busca aproximar a aparente utopia da realidade. Finalmente, cabe salientar a contribuição à discussão do conceito de sustentabilidade, representada pelas cinco dimensões antes descritas, em particular a dimensão espacial, usualmente desconsiderada em muitas das tentativas de detalhamento do tema.

Fica claro que desenvolvimento e meio ambiente eram vistos como questões separadas, embora já se preconizasse o compromisso simultâneo de preservação do meio ambiente e de uso racional dos recursos. Esta necessidade de um compromisso simultâneo iria gerar uma clivagem que marcou profundamente o debate subsequente, qual seja, aquela que enfatiza as diferenças quanto aos condicionantes impostos aos países do chamado primeiro e terceiro mundo: o desenvolvimento dos países hoje industrializados se fez às custas, entre outros fatores, de recursos naturais globais, enquanto os demais se veem frente ao desafio de superar suas limitações históricas sem lançar mão da dilapidação extensiva de tais recursos, prevalecente nas primeiras fases do processo de industrialização. Esta faceta norte-sul do debate, se assim se pode denominá-la, adquire um peso considerável nas abordagens institucionais, constituindo um elemento importante nas discussões acerca dos limites e possibilidades da sustentabilidade.

Cadernos do Leste

Artigos Cientificos

Belo Horizonte, Edição Especial, 2000 a 2008 
Um segundo aspecto diz respeito à diversidade de posições existentes na Conferência de Estocolmo, representando diferentes formas de analisar as relações entre desenvolvimento e meio ambiente ${ }^{5}$. $\mathrm{Na}$ avaliação de SACHS (1993), os resultados da Conferência representaram um "caminho intermediário" entre visões extremadas ${ }^{6}$, tanto daqueles que depositavam uma fé inquebrantável na tecnologia (e na capacidade inesgotável do capitalismo em superar suas crises, bem como as limitações impostas pela natureza), quanto daqueles que previam a iminência da catástrofe demográfica e ecológica ${ }^{7}$. Tal opção, para o autor, representou uma

"mensagem de esperança sobre a necessidade e a possibilidade de se projetar e implementar estratégias ambientalmente adequadas para promover um desenvolvimento equitativo, ou eco desenvolvimento, uma expressão que foi mais tarde rebatizada pelos pesquisadores anglo-saxões como desenvolvimento sustentável." (SACHS, 1993, p. 2930)

Um terceiro aspecto subjacente ao debate que se explicita a partir da década de setenta, diz respeito à considerável parcela de responsabilidade atribuída à dinâmica demográfica quanto à desigualdade dos resultados da distribuição dos frutos do crescimento econômico e quanto à crescente pressão sobre os recursos naturais (e também sobre recursos humanos, sociais, fiscais, etc). Existe uma literatura relativamente farta sobre população e meio ambiente, na qual se destacam de início abordagens de cunho neomalthusiano, cujo objetivo final era justificar a necessidade de controle populacional. $\mathrm{O}$ caráter simplista e a postura, de certa forma, preconceituosa presentes em tais abordagens foram apontados por trabalhos pioneiros no Brasil, como HOGAN (1989) e, posteriormente, MARTINE (1993), deslocando-se, a partir daí, o eixo da discussão (e das

\footnotetext{
${ }^{5}$ Embora fuja aos objetivos do texto, cabe registrar a controvertida posição brasileira na Conferência, em reação às propostas a partir das quais temas como soberania nacional entrelaçavam-se com as questões ambientais. A esse respeito, ver, por exemplo, GUIMARÃES (1989) e FERREIRA (1993).

${ }^{6}$ Note-se que o processo preparatório destas grandes conferências tem sido, em muitos casos, tão ou até mais importante do que o momento da conferência em si, particularmente no que diz respeito à discussão de conceitos e de estratégias a serem consubstanciados nos documentos encaminhados. Aqui o autor se refere ao Relatório Founex, documento síntese de uma importante reunião preparatória para a Conferência, editado no mesmo ano.

${ }^{7} \mathrm{O}$ documento que melhor representa a visão catastrófica é o também seguidamente mencionado relatório do chamado Clube de Roma, datado de 1972 e intitulado "The limits to Growth". Conforme sugere o título, o remédio possível seria a contenção tanto do crescimento econômico como do demográfico.
}

Cadernos do Leste

Artigos Cientificos

Belo Horizonte, Edição Especial, 2000 a 2008 
pesquisas) para a construção de referenciais teóricos e empíricos de natureza crescentemente interdisciplinar ${ }^{8}$.

A Conferência de Estocolmo sobre o Meio Ambiente Humano, em 1972, é um marco desta discussão. Entretanto, já no encontro preparatório em Founex, em 1971, iniciava-se uma reflexão a respeito das implicações de um modelo de desenvolvimento, baseado exclusivamente no crescimento econômico, sobre o meio ambiente. Duas foram as teses discutidas durante o evento:

"de um lado os zeristas, representados pelos países desenvolvidos, que defendiam a contenção do crescimento econômico frente à provável esgotabilidade dos recursos naturais que o ritmo da exploração da natureza poderia causar (mantidas as projeções de crescimento do PIB mundial), isto é, propunham o crescimento zero para os países dependentes, congelando-os no estágio em que se encontravam; de outro, os desenvolvimentistas, cujos adeptos eram em sua maioria países do chamado Terceiro Mundo, reivindicando o desenvolvimento, mesmo que este trouxesse consigo a poluição. Vale enfatizar que ambas as correntes reforçam o modelo de desenvolvimento instalado, pois os zeristas não previam a estagnação do crescimento das atividades nos países desenvolvidos." (EVASO et al, 1996)

No mesmo ano (1972), foi publicado pelo Clube de Roma o estudo intitulado Os limites do crescimento. Segundo Bruseke, as teses e conclusões do grupo de pesquisadores coordenados por Dennis Meadows são:

"1. Se as atuais tendências de crescimento da população mundial industrialização, poluição, produção de alimentos e diminuição de recursos naturais continuarem imutáveis, os limites de crescimento neste planeta serão alcançados algum dia dentro dos próximos cem anos. O resultado mais provável será um declínio súbito e incontrolável, tanto da população quanto da capacidade industrial.

2. É possível modificar estas tendências de crescimento e formar uma condição de estabilidade ecológica e econômica que se possa manter até um futuro remoto. $\mathrm{O}$ estado de equilíbrio global poderá ser planejado de tal modo que as necessidades materiais básicas de cada pessoa na Terra sejam satisfeitas, e que cada pessoa tenha igual oportunidade de realizar seu potencial humano e individual.

3. Se a população do mundo decidir empenhar-se em obter este segundo resultado, em vez de lutar pelo primeiro, quanto mais cedo ela começar a trabalhar para

\footnotetext{
${ }^{8}$ Ver HOGAN \& VIEIRA (1992); FERREIRA \& VIOLA (1996); PAULA et al (1997).

Cadernos do Leste

Artigos Cientificos

Belo Horizonte, Edição Especial, 2000 a 2008
} 
alcançá-lo, maiores serão suas possibilidades de êxito.” (MEADOWS apud BRUSEKE, 1995)

Para alcançar a estabilidade econômica e ecológica, o documento propõe o congelamento da população global e do capital industrial, ou seja, a tese do crescimento zero de forte influência malthusiana. A linha de pensamento desta tese é, até hoje, foco de discussões e divergências que se manifestam em conferências internacionais, quando os representantes do Terceiro Mundo enfatizam a necessidade inadiável de crescimento que seus países têm, assim como a tiveram os países hoje tidos como desenvolvidos. Enfim, esta tese vem colocar definitivamente em confronto no debate global, a questão ambiental e os desequilíbrios socioeconômicos.

\section{iii) O desenvolvimento sustentável e suas bases de sustentação político-social:}

Um aspecto importante, a ser considerado no debate acerca da conceituação de desenvolvimento sustentável, é aquele que busca identificar suas bases de sustentação político-sociais, ou seja, os principais atores envolvidos, as prioridades a serem estabelecidas, os principais elementos em torno dos quais articulam-se as estratégias. Com base em tais parâmetros, VIOLA \& LEIS (1992) identificam as três versões de desenvolvimento sustentável, permeadas por diferentes valores ético-sociais de difícil aproximação mútua:

Estatista - considera a qualidade ambiental como um bem público que, como tal, "somente pode ser resguardado eficientemente através de uma incisiva intervenção normativa, reguladora e promotora do Estado.” (VIOLA \& LEIS, 1992, p. 79-80). Associa-se ao surgimento de ONGs (organizações não-governamentais), bem como de políticas e agências ambientais na Europa Ocidental e Estados Unidos. Articula-se, em torno da combinação entre eficiência alocativa (de recursos) e equidade social $\mathrm{O}$ enfoque estatista estava, à época, envolvendo uma maioria dos técnicos das Cadernos do Leste 
agências ambientais, das ONGs ambientalistas ( $1^{\circ}$ mundo). Os empresários e gerentes eram absolutamente minoritária;

Comunitária - considera que as organizações de base da sociedade (grupos comunitários e ONGs) devem desempenhar papel central na transição para o desenvolvimento sustentável, desconfiando tanto do Estado quanto do mercado, enquanto atores principais do processo. Imprime grande valor aos avanços locais e regionais e privilegia a equidade social. Há, aqui, uma valorização das iniciativas locais e regionais e uma priorização do princípio da equidade social por sobre a eficiência alocativa. É o setor, segundo os autores, com um maior componente utópico, estando representado, principalmente, pelas ONGs atuantes no Terceiro Mundo e, numa escala mais reduzida, pelas do Primeiro Mundo;

De mercado - o avanço rumo ao desenvolvimento sustentável efetiva-se pela lógica do mercado, com apropriação privada dos recursos naturais e da qualidade ambiental. Prevê a expansão do chamado "consumidor verde". Prioriza a eficiência alocativa dos recursos. Considera necessária tanto a existência de mecanismos estatais reguladores, como a atuação educativa das ONGs, ambas subordinadas aos mecanismos de mercado. Há, aqui, uma forte crítica do sistema de regulação social, considerado ineficiente e uma legitimação da apropriação privada dos bens ambientais, estando sua preservação ligada à demanda dos consumidores. Constitui um enfoque em expansão no mundo empresarial e entre certos economistas ambientais.

Embora difícil de ser encontrada em estado puro, cada "versão" de desenvolvimento sustentável deixa claro que, pelo menos no nível do discurso, o conceito de sustentabilidade foi incorporado pelos diversos segmentos da sociedade. Por outro lado, conforme já apontado anteriormente, permanecem em aberto as muitas opções (e, naturalmente, suas consequências) em termos dos caminhos a serem percorridos. 
Assim, o desenvolvimento sustentável (da mesma forma que o "desenvolvimento" sem adjetivos em décadas anteriores) permanece um ponto de chegada, ou uma utopia como diria VEIGA9 (1993), balizando as opções que se colocam às sociedades contemporâneas nesta passagem para o próximo século.

\section{iv) Colby: a evolução dos paradigmas acerca do gerenciamento ambiental}

A ideia segundo a qual o desenvolvimento sustentável corresponde a um ponto de chegada a ser alcançado pela sociedade contemporânea é também compartilhada por COLBY (1990). Tendo como eixo de partida a noção de gerenciamento/gestão, este autor apresenta uma interessante sistematização daquilo que denomina a evolução dos paradigmas de gerenciamento/gestão ambiental, envolvendo graus diferenciados de planejamento, intervenção e controle nas relações entre homem e natureza. Sua hipótese principal é que, ao longo do tempo, dentro dos marcos da sociedade industrial, tem havido mudanças profundas nas concepções e metodologias de gerenciamento ambiental e em sua relação com o desenvolvimento humano. Tais mudanças caminham no sentido da convergência de dois campos separados: o da economia à qual tradicionalmente se associa a noção de desenvolvimento, e o da ecologia, usualmente veiculando, usualmente, a ideia de preservação da natureza. Dessa forma, a cada momento no tempo, correspondendo a cada um dos paradigmas, as diferentes estratégias de gerenciamento ambiental buscam responder às seguintes questões: o que é economicamente prático? $O$ que é tecnologicamente possível? O que é ecologicamente necessário? E o que é politicamente operacionalizavel?

Cada paradigma percebe diferentes evidências, prioridades e problemas, sugerindo diferentes soluções, estratégias, tecnologias e papéis para os setores da economia, cultura,

\footnotetext{
${ }^{9} \mathrm{O}$ autor sugere que as diversas versões do desenvolvimento sustentável refletiriam a necessidade de uma nova utopia que viria a caracterizar uma nova etapa histórica, sucedendo a presente etapa da sociedade industrial. Assim, na visão do autor, no momento presente estar-se-ia vivendo uma situação semelhante às chamadas utopias do século XIX, onde Owen, Fourier, Saint-Simon, entre outros, procuravam unir numa equação ideal, formas de organização da Cadernos do Leste Artigos Cientificos 
governo, critérios éticos, entre outros. São cinco paradigmas: economia de fronteira, proteção ambiental, gerenciamento de recursos, eco desenvolvimento e ecologia radical.

O primeiro, a economia de fronteira, de cunho fortemente antropocêntrico, corresponde à experiência histórica de evolução do capitalismo nos países hoje industrializados, baseia-se na noção de "progresso", que corresponde a um crescimento econômico "infinito" pelo uso ilimitado de recursos naturais. Em contraposição ao primeiro, define-se o último paradigma, conhecido como ecologia radical ou profunda (do inglês, "deep ecology"), de caráter marcadamente biocêntrico, baseia-se em conceitos como a biorregião, a democracia entre as espécies, a restrição ao crescimento demográfico e urbano, a volta à natureza. Muitas vezes criticado por um certo saudosismo, dificilmente incorpora em seus postulados os avanços tecnológicos, políticos, sociais ou comportamentais da chamada civilização urbano-industrial. Por outro lado, sua maior virtude reside no fato de trazer à tona uma outra ética na relação com a natureza, ao mesmo tempo em que resgata a visão do todo e não da fragmentação. Enfatiza, também, valores não necessariamente materiais como o "bem-comum" em substituição à ética individualista tida como natural pelo capitalismo. (PÁDUA, 1989)

Os demais paradigmas correspondem a uma progressiva incorporação da dimensão ambiental nas esferas da produção e da gestão dos recursos. Assim, o paradigma definido como "proteção ambiental", de caráter eminentemente remediativo, entre outras propostas, começa a introduzir alguns mecanismos de controle de atividades poluentes, privilegiando atitudes de "trade off" entre ecologia e crescimento econômico. O próximo, denominado de "gerenciamento de recursos", já considera a existência de certo grau de interdependência entre Ecologia e Economia estabelecendo princípios como poluidorpagador, ou ainda, as avaliações de impacto ambiental como estratégias importantes de

sociedade e formas de ocupação do espaço, no caso, por meio de propostas de modelos urbanísticos considerados compatíveis com uma sociedade mais igualitária.

Cadernos do Leste

Artigos Cientificos

Belo Horizonte, Edição Especial, 2000 a 2008 
gerenciamento ambiental. O paradigma considerado pelo próprio autor como a situação desejável é denominado "eco desenvolvimento" e busca uma redefinição de papéis nas esferas pública e privada. Tem caráter preventivo, considera, simultaneamente, mudanças globais e a necessidade de uma tecnologia que incorpore critérios sociais, econômicos e ecológicos. Trata-se do paradigma que corresponderia mais de perto à noção de desenvolvimento sustentável que se pretendeu discutir.

O esquema proposto por COLBY (1990) é, como qualquer tentativa de sistematização, extremamente teórico, e, dificilmente pode-se encontrar, no momento atual, uma situação real que se encaixe integralmente num dos paradigmas. Pelo contrário, dependendo do aspecto a ser considerado, uma mesma realidade, muitas vezes, incorpora elementos de vários deles simultaneamente. Este parece ser o maior mérito desta contribuição, de permitir, a partir de um esquema básico, inúmeras possibilidades de comparações, no tempo, várias situações num mesmo momento, além de estimular a utilização do mesmo processo de sistematização por outras áreas de intervenção correlatas, como gestão urbana, gestão de políticas sociais, entre outras.

\section{3 - A polêmica entre crescimento e desenvolvimento}

Segundo EVASO et al (1996), existe um consenso sobre o que seja crescimento entre as correntes conservadoras (neoliberais e neomalthusianos) e as vertentes marxistas. As controvérsias se dão a respeito do destino dos resultados do crescimento, destino ao qual se dá o nome de desenvolvimento. Como os destinos podem ser muitos, pode-se dizer que há um número equivalente de discernimentos sobre a ideia de desenvolvimento.

O crescimento diz respeito à renda global, baseando-se na expansão produtiva dos vários subconjuntos econômicos. É definido por novas tecnologias e produção de novas necessidades, ou, simplesmente, pela localização de novas unidades produtivas. Ainda 
segundo os autores, o crescimento não implica mudanças nas relações sociais de produção, nem combinação de fatores no setor produtivo. Em outras palavras, o crescimento, sendo econômico, é expansão da renda bruta que uma dada e determinada economia pode gerar. Tem, portanto, uma forte conotação capitalista, refletindo, em última instância, uma maior produção de mercadorias e uma maior circulação de capital.

O desenvolvimento, ainda segundo os mesmos autores, não se dá por igual na superfície terrestre: o capital é espacialmente concentrado e móvel, dirigindo-se sempre às áreas, oferecem as mais altas taxas de rentabilidade, que, por sua vez, são função, entre outras coisas, da implementação de políticas regionais e locais de desenvolvimento. (EVASO et ali, 1996) Acontece que, além de espacialmente concentrado, o capital é também, socialmente concentrado, pois os mecanismos de mercado não garantem um equilíbrio na distribuição da renda, tudo isso gerando o que se pode chamar de desenvolvimento desigual.

Os referidos autores distinguem dois tipos de desenvolvimento: um quantitativo e outro qualitativo. O quantitativo, de raízes ricardianas, é apregoado pelos zeristas, neomalthusianos ${ }^{10}$ e neoliberais ${ }^{11}$. Este desenvolvimento é resultado de inversões marginais de capital sob a lógica das vantagens comparativas dos lugares, não se observando nenhuma diferença de fundo, entre crescimento e desenvolvimento quantitativo. Já o qualitativo, reconhece o desenvolvimento desigual, atribuindo aos agentes históricos o papel modificador de estruturas vigentes. Aqui, o desenvolvimento associa-se com

\footnotetext{
${ }^{10} \mathrm{O}$ neomalthusianismo representa uma ressurgência do pensamento de Malthus após a II Grande Guerra, momento em que ganhou grande notoriedade mundial e motivou a ação de diversos organismos internacionais preocupados com a questão demográfica. Os países ricos pressupunham que o ritmo elevado de crescimento populacional dos países subdesenvolvidos comprometeria os recursos naturais do planeta pondo em risco a própria existência da espécie humana. Nessa nova versão, mais do que o provimento de recursos alimentares, os neomalthusianos chamavam a atenção para a finitude dos recursos ambientais, vis-à-vis a ação antrópica que degrada elementos da natureza vitais à sobrevivência humana, tais como a água, os solos, a vegetação, o clima, etc.

${ }^{11}$ A concepção neoliberal associa-se aos que advogam o mercado como a melhor instância para solução dos problemas de crescimento e desenvolvimento econômico, entendendo que o sistema de preços produz a alocação eficiente de recursos escassos. Neste caso, quaisquer ingerências governamentais no mercado produziriam distorções no sistema produtivo.
}

Cadernos do Leste

Artigos Cientificos

Belo Horizonte, Edição Especial, 2000 a 2008 
qualidade de vida, e com um maior nível de democratização dos frutos do crescimento econômico.

A dicotomia que parece ser fundamental é, de um lado, um enfoque economicista (o crescimento e o desenvolvimento quantitativo) e de outro um enfoque que incorpora dimensões sociais da vida (embora sejam várias as formas de se tratá-lo): o desenvolvimento não pode ser só econômico, mas, também, social - daí a necessidade de se falar em desenvolvimento socioeconômico.

Nesta mesma linha, também, explica-se a criação pela ONU do Índice de Desenvolvimento Humano (IDH), noticiado pela primeira vez no Relatório do Desenvolvimento Humano, em 1990. Ele se baseia na definição de desenvolvimento como "um processo de ampliação do campo de oportunidades oferecidas à população de um país.”.(PENTEADO, 1994) Somam-se aos recursos econômicos de que dispõe o indivíduo, a saúde, a longevidade e a educação. Ao invés simplesmente do $\mathrm{PNB}^{12}$ global de um país e de seu PNB per capita, são medidos, também, a expectativa de vida ao nascer, o grau de escolaridade e alfabetização da população.

O exemplo brasileiro é bastante ilustrativo para se ter noção da diferença entre os dois enfoques. Medindo-se apenas o PNB per capita, o Brasil ocupava, em 1992, o $37^{\circ}$ lugar entre os 125 países do planeta. Entretanto, para o IDH, em 1991, o Brasil ocupava o $60^{\circ}$ posição. (PENTEADO, 1994) Este dado mostra claramente o caráter concentrador do capitalismo brasileiro, que gerou mais crescimento econômico do que desenvolvimento humano/social.

Convém recordar que, ainda na década de 70, avançou mais uma etapa na evolução do então incipiente debate ambiental, culminando, ao final da década, com a proposta do eco desenvolvimento. Na Conferência de Estocolmo, em 1973, o canadense Maurice

\footnotetext{
${ }^{12}$ Convém lembrar que o PNB é o valor monetário dos bens e serviços finais produzidos pelo país, diferentemente do $\mathrm{PIB}$, que subtrai do PNB a renda líquida enviada para o exterior.

Cadernos do Leste

Artigos Cientificos

Belo Horizonte, Edição Especial, 2000 a 2008
} 
Strong traz à cena, pela primeira vez, o conceito de eco desenvolvimento para caracterizar uma concepção alternativa de desenvolvimento. (BRUSEKE, 1995). Foi, porém, Ignacy Sachs quem formulou mais claramente este conceito cuja principal aspiração é a de "definir um estilo de desenvolvimento particularmente adaptado às regiões rurais do Terceiro Mundo, o que não significa não se poder estendê-lo às cidades.” (SACHS, 1986, p.15). As idéias do eco desenvolvimento, segundo Brüseke, explicitam uma clara relação com a teoria do "self-reliance", defendida nas décadas anteriores por Mahatma Gandhi ou Julius Nyerere.

A variável ambiental tornava-se o mais novo fator complicador da equação do desenvolvimento. Introduzia-se a problemática da escala (e da capacidade de suporte dos ecossistemas), enfrentada pelos teóricos da economia ecológica como Daly, economista do Departamento de Meio Ambiente do Banco Mundial. Sua preocupação focalizava a questão da escala da ação humana no planeta, aproximando-se dos defensores da tese do crescimento zero. Perguntava: "Qual é a grandeza, afinal, do subsistema humano em relação ao ecossistema total?” (DALY, 1991, p. 6). Tomava como base para essa ambiciosa mensuração, a porcentagem da produção primária líquida, derivada da fotossíntese apropriada pelos seres humanos, que seria da ordem de $25 \%$ para o ecossistema total, e de $40 \%$ para os ecossistemas terrestres. Sendo assim, a economia humana poderia no máximo ser multiplicada por quatro.

Entretanto afirma o autor:

" $\mathrm{Na}$ verdade, há muitas evidências de que a escala atual já é insustentável. Contudo, essa constatação serve apenas para tornar ainda mais aguda a contradição frente à visão proposta pelo relatório Brundtland, de acordo com o qual o desenvolvimento sustentável necessitaria do crescimento da economia mundial da ordem de 5 a 10 vezes." (DALY, 1991, p. 6)

O autor observa que "o tamanho ótimo do nicho humano seria, do ponto de vista biocêntrico, menor que o ótimo do ponto de vista antropocêntrico. No julgamento da maioria das pessoas, a característica básica que qualquer dos “ótimos” deve ter é a Cadernos do Leste Artigos Cientificos 
sustentabilidade." (DALY, 1991, p 7). Defende, ainda, a manutenção da escala da atividade humana em um nível suficientemente baixo, de forma a não destruir o funcionamento automático dos sistemas que sustentam a vida. Também ironiza os que acreditam na "mão invisível" do mercado para regular a escala da atividade humana visando à sustentabilidade. Enfim, Daly se mostra crítico a qualquer conceito de sustentabilidade que se baseie em, ou que traga embutido, na sua concepção, a necessidade de crescimento econômico. Isto é refletido na sua definição de desenvolvimento sustentável:

"O desenvolvimento sustentável é desenvolvimento sem crescimento, sendo que:

a - crescimento significa aumento de tamanho por adição de material através de assimilação ou acréscimo (ou seja, aumento quantitativo);

b - desenvolvimento significa expansão ou realização de potencialidades, levando, gradualmente, a um estado mais pleno, maior ou melhor (ou seja, melhoria qualitativa).

Em outras palavras, desenvolvimento sustentável é uma melhoria qualitativa que não implique um aumento quantitativo maior do que o aceitável pela capacidade de suporte, ou seja, a capacidade do ambiente de regenerar os inputs de matéria prima e absorver os outputs residuais." (DALY, 1991, p. 14)

O tipo de enfoque de Daly, embora procure esmiuçar a questão dos limites ecossistêmicos, tem pelo menos três problemas:

Sua excessiva preocupação com a escala acaba levando-o à armadilha malthusiana: o controle populacional, evidentemente, voltado para os países pobres;

Sua linha de raciocínio remete à idéia de que todo tipo de atividade humana é igualmente predatória, não abordando possibilidades de uso sustentável dos ecossistemas, nos quais a questão da escala se colocaria de forma muito diferenciada em relação a usos predatórios - esta questão está intimamente ligada às formas de relação homem/natureza, e aos paradigmas que as regem (questão que Daly também não considera na sua análise). $\mathrm{O}$ autor também não faz menção às enormes diferenças no consumo dos recursos entre países e populações ricas e pobres;

Cadernos do Leste

Artigos Cientificos

Belo Horizonte, Edição Especial, 2000 a 2008 
Sua conceituação é restrita à relação Economia/Ecologia.

\section{4 - Sustentabilidade e capitalismo}

Todas estas questões são, em grande parte, função do modelo de sociedade em que vivemos, de seu sistema socioeconômico e político, de sua ciência, de sua cultura, etc. A partir destas questões, alguns autores procuram destacar as ambiguidades do conceito de desenvolvimento sustentável.

Para Evaso et al, o discurso do desenvolvimento sustentável ora serve para resgatar a funcionalidade do sistema capitalista, ratificando-o (eco capitalistas); ora para questionar sua estrutura, propondo sua substituição (eco socialistas). Para os primeiros, "a expansão econômica é necessária, e pode estar em harmonia com a proteção ambiental" (EVASO et al, 1996, p. 97), enquanto os últimos denunciam as causas da degradação ambiental e da pobreza como sendo consequências do modo de produção capitalista e de seus mecanismos excludentes: o sistema de mercado, a globalização perversa e o consumismo alienante. "Portanto, a pobreza não seria a causa da degradação ambiental como querem fazer crer os eco capitalistas. Esta inversão dos agentes causadores dos desequilíbrios ambientais é empregada para se justificar a continuidade do modelo gerador de desigualdades, bem como a expansão do mercado e do lucro.” .(EVASO et al, 1996, p. 98)

Acselrad (1993) também enfatiza o caráter ideológico presente na disputa em torno da noção de desenvolvimento sustentável, pois

"ao longo desta nova disputa comparecem também velhos atores que utilizam esta nova noção de desenvolvimento como simples instrumento para encobrir e legitimar velhas práticas. Multiplicam-se assim as "empresas sustentáveis" ou as propostas de "sustentabilidade pelo livre comércio’. Isto é o que o Greenpeace chamou de marketing verde de empresas e governos...” (ACSELRAD, 1993, p. 5)

Ainda para Acselrad, existem duas linhas básicas de interpretação da crise ambiental: 
"A primeira reconhece a incapacidade do mercado em respeitar os limites do meio ambiente e propõe a criação de elementos sinalizadores que permitam assegurar a continuidade do modelo de desenvolvimento capitalista. A segunda linha de interpretação entende a crise ambiental como manifestação de uma crise no modelo capitalista de desenvolvimento e identifica os caminhos de sua superação na introdução de mudanças na estrutura de poder sobre os recursos naturais." (ACSELRAD, 1993, p. 5)

A privatização dos recursos naturais é para o autor uma questão-chave do processo de degradação ambiental. Em síntese, ele afirma que pela acumulação extensiva, o capital aumenta seus lucros ampliando a escala de produção, utilizando, consequentemente, mais matérias-primas e recursos naturais. A aceleração dos ritmos de exploração da natureza termina por chocar-se com os ritmos de regeneração dos próprios ecossistemas. "Desta forma, os capitais lançam no meio ambiente comum - atmosfera, rios, marés e solos - uma ampla gama de materiais. São produtos invendáveis de sua atividade - os chamados resíduos sólidos, os efluentes líquidos e gasosos.” (ACSELRAD, 1993, p. 8)

O autor defende que a solução da crise ambiental passa pela democratização do controle sobre os recursos naturais e pela desprivatização do meio ambiente comum. "Sob esta ótica, é preciso alterar as estruturas de poder que condicionam o uso do meio ambiente, colocando limites ao controle do capital sobre a natureza.” (ACSELRAD, 1993, p. 8) A batalha, então, dá-se prioritariamente no campo da política, e não no campo da economia e do mercado. Então, segundo o autor, as lutas sociais de populações atingidas pela concentração crescente do controle dos recursos naturais devem se pautar pela adoção de medidas que tornem efetivamente público o meio ambiente comum.

Já Stahel vai abordar a compatibilidade ou não do capitalismo com a sustentabilidade por um outro ângulo. Seu centro de análise se dá a partir da segunda lei da termodinâmica $^{13}$ - a lei da entropia -, já que o que ameaça a sustentabilidade do processo econômico é justamente a base material que lhe serve de suporte, bem como a capacidade do meio de absorver a alta entropia resultante do processo econômico. Segundo Stahel: 
"Em sua formulação mais simples, nós podemos ver a tendência a uma entropia crescente de um sistema fechado, dada pela segunda lei da termodinâmica, como uma tendência à transformação de energia livre ou disponível em uma energia dissipada ou presa e não mais disponível. Trata-se de uma transformação qualitativa, já que do ponto de vista quantitativo, no sistema como um todo, continua prevalecendo a lei da conservação da matéria e da energia, dada pela $1^{\mathrm{a}}$ lei da termodinâmica. Enquanto a $1^{\mathrm{a}}$ lei da termodinâmica afirma que em um sistema fechado a quantidade de energia e matéria é invariável (sendo compatível com o paradigma newtoniano), a segunda lei da termodinâmica, ou lei da entropia, ao apontar para um movimento irreversível, unidirecional e para uma alteração qualitativa, põe em xeque a física mecânica e a sua visão circular, reversível e puramente quantitativa do movimento. A queima de carvão em cinzas é um exemplo de um fenômeno entrópico, como o são o desgaste dos pneus no asfalto, a oxidação dos metais e o fluir das águas para o mar. O nível entrópico seria, nesse sentido, um índice de disponibilidade de energia e matéria em sua forma ordenada, ou, em termos gerais, da ordem de um sistema."(STAHEL, 1995)

Para o autor, a vida sustenta-se na capacidade de manter a estrutura frente à pressão e ao desgaste da entropia (da morte).

A busca de expansão constante é inerente ao próprio capitalismo. Citando Marx: “a circulação do dinheiro como capital, ao contrário, tem sua finalidade em si mesma, pois a expansão do valor só existe nesse movimento continuamente renovado. Por isso, o movimento do capital não tem limites.” (MARX apud STAHEL, 1995, p. 107)

Este objetivo do capitalismo é puramente quantitativo; é a primazia do valor de troca sobre o valor de uso, sancionado pela uni dimensionalidade do mercado. O autor afirma:

"Calcado em um critério monetário, quantitativo e unidimensional, o mercado direciona e sanciona os desenvolvimentos compatíveis com a lógica de acumulação e de expansão capitalista. A eficiência produtiva, mesmo que às custas de uma ineficiência social ou de uma ineficiência ambiental (as externalidades negativas para os economistas), é uma necessidade de sobrevivência no quadro de um capitalismo de mercado.” (STAHEL, 1995, p. 107)

\footnotetext{
${ }^{13}$ As leis da termodinâmica foram formuladas por R. Clausius em 1865.

Cadernos do Leste

Artigos Cientificos

Belo Horizonte, Edição Especial, 2000 a 2008
} 
STAHEL (1995) argumenta, ainda, que várias culturas os critérios de sanção social responsáveis, por exemplo, pela adoção ou não de uma nova tecnologia, são calcados em critérios qualitativos (culturais, éticos e religiosos, como o são as tradições, as crenças místicas, os valores comunitários, etc). No capitalismo, entretanto, tal desenvolvimento será sancionado e dirigido pelas forças de mercado.

A entropia caracteriza-se justamente por dar conta de um fenômeno qualitativo: a mudança de um estado (baixa entropia) para outro (alta entropia). "A sustentabilidade material do processo econômico repousa nesse limite qualitativo, na baixa entropia (energia e estruturas materiais ordenadas) disponíveis no início do processo, frente à alta entropia (energia e estruturas materiais dispersas) resultante no final do processo.” (STAHEL, 1995, p. 108)

Mais a frente o autor afirma:

"Quando falamos de desenvolvimento sustentável, temos que considerar não só os aspectos materiais e econômicos, mas o conjunto multidimensional e multifacetado que compõe o fenômeno do desenvolvimento: os seus aspectos políticos, sociais, culturais e físicos. A sustentabilidade do todo só pode repousar na sustentabilidade conjunta de suas partes. Esses fatores e os seus respectivos equilíbrios repousam sobre fatores qualititivos, como o são os graus de coesão e harmonia social, questões como cidadania, alienação, valores éticos e morais, o grau de polarização social e política, os valores da sociedade e o nível entrópico do sistema.” (STAHEL, 1995, p. 108-109)

A vida, segundo o autor, afirma-se enquanto capacidade de resistência frente à degradação entrópica, e a biosfera assegura sua sobrevivência pela busca constante de estabilidade e manutenção do nível de baixa entropia. Esta propriedade repousa na sua capacidade de reciclagem. $\mathrm{Na}$ Terra,

“a degradação entrópica do ponto de vista energético é mais do que compensada pela contínua absorção e transformação da baixa entropia solar, sendo também está energia que permite a permanente transformação e reciclagem material. [...]. Lutando contra a degradação entrópica e buscando a estabilidade, o tempo da biosfera é um tempo circular, dos ciclos circulares e da contínua reciclagem. As mudanças se dão apenas em face das mudanças exteriores à biosfera, buscando-se a partir de então um

Cadernos do Leste

Artigos Cientificos

Belo Horizonte, Edição Especial, 2000 a 2008 
novo equilíbrio circular. É este tempo circular, da busca constante da estabilidade, manifesto nas ideias de eterno e na busca constante de repetir um ideal mítico passado, que também marca as sociedades tradicionais (Eliade,1985). Com a sociedade capitalista, pela primeira vez nos deparamos com uma sociedade calcada não na busca de estabilidade, mas sim na busca constante da mudança, da instabilidade. Do eterno retorno ao mesmo, passamos ao progresso. Do tempo circular, passamos ao tempo evolutivo." (STAHEL, 1995, p. 112)

Há, no capitalismo, portanto, um descompasso temporal entre o subsistema econômico (curtíssimo prazo) com o sistema planetário como um todo (tempo geobiológico). $\mathrm{O}$ autor conclui afirmando que a lei da entropia aponta para os limites materiais e energéticos enquanto que o capital aponta para uma necessidade de expansão infinita. Neste aspecto, um capitalismo de crescimento zero é uma total incongruência. (STAHEL, 1995)

Também LEFF (1994) assinala incompatibilidades insuperáveis entre a racionalidade ambiental e a racionalidade capitalista. A partir de Marx e de sua teoria que aborda a lógica do capitalismo a partir do trabalho, como transformador da natureza e como produtor do valor de troca e da mais valia, Leff vai buscar as conexões entre acumulação capitalista e a degradação da natureza:

"Com la acumulacion capitalista, las conexiones entre procesos sociales y procesos naturales se producen por la inscripcion de los procesos de trabajo productores de valores de uso dentro de procesos productivos de plustrabajo o plusvalor. En este sentido, los procesos de trabajo se conviertem en um simple medio para la producción de valores de cambio, de mercancias. La produccion de plusvalor aparece como el fin último del proceso productivo, determinando um proceso de innovación tecnológica (la aplicación del conocimiento científico a la producción) como mecanismo eficaz para aumentar la extracción de plusvalor relativo, por el incremento de la productividad de las fuerzas de la naturaleza y su transformación en fuerzas productivas de capital." (LEFF, 1994, p. 145)

A reprodução das relações de produção capitalistas foram determinando a aparição de novos ramos produtivos, articulados ao incremento da demanda e do consumo de mercadorias. Isso gerou a necessidade de explorar cientificamente a natureza, convertendoa em objeto útil, enquanto cresceu a ignorância dos processos ecossistêmicos.

Cadernos do Leste

Artigos Cientificos

Belo Horizonte, Edição Especial, 2000 a 2008 
Simultaneamente, o capitalismo foi levando à concentração do poder econômico e político, à homogeneização dos modelos produtivos e dos padrões de consumo e estilos de vida. Foram se desestabilizando, por conseguinte, os processos ecológicos; as práticas tradicionais de uso dos recursos; as identidades e solidariedades dos grupos culturais.

Segundo o autor, o progresso técnico induzido pela acumulação capitalista esteve fortemente orientado para a elevação da produtividade dos bens de produção, sem considerar o esgotamento dos recursos fósseis e minerais nem a sustentabilidade dos ecossistemas produtivos. Rompem-se os mecanismos de organização biológica dos ecossistemas, e aumenta a entropia dos processos econômicos e tecnológicos. Entretanto, Leff ressalta que os efeitos mais negativos deste processo se manifestaram pela transferência das mesmas tecnoestruturas aos países subdesenvolvidos.

"La dependência econômica de estos países há implicado la adopción de modelos inadecuados de industrialización, de urbanización y de uso de los recursos naturales. La imitación de patrones de consumo y de formas de organización productiva de los países altamente industrializados provoca niveles más altos de contaminación y procesos más graves de destrucción de sus recursos. La transferencia mimética de modelos tecnológicos de las zonas templadas há llevado a una degradación de la capacidad productiva de los agroecosistemas tropicales, sobre todo en el trópico cálido húmedo.” (LEFF, 1994, p. 199)

Leff aborda o discurso do desenvolvimento sustentável no novo contexto neoliberal globalizante e suas contradições com o conceito anterior do eco desenvolvimento (LEFF, 1996, 1997). A superação deste conceito pelo primeiro associa-se com a conjuntura dos anos 80, em particular na América Latina, quando seus países se viram aprisionados pela dívida externa, por processos inflacionários e recessivos. A recuperação econômica passou a ser a prioridade das políticas governamentais. Nesse contexto, o Estado planejador, no qual estavam ancoradas as estratégias de adoção das propostas do eco desenvolvimento, vai perdendo este papel. Materializavam-se os programas neoliberais de diferentes países, ao mesmo tempo que se aprofundavam os problemas ambientais. Neste momento, começa a cair em desuso o discurso do eco Cadernos do Leste Artigos Cientificos 
desenvolvimento, sendo substituído pelo de desenvolvimento sustentável. Apesar de alguns princípios comuns de ambos os discursos, o autor aponta que as estratégias de poder da ordem econômica dominante vêm modificando o conceito ambiental crítico do discurso do eco desenvolvimento para submetê-lo à racionalidade do crescimento econômico. (LEFF, 1997). Ao invés do planejamento estatal de estratégias e iniciativas no rumo do eco desenvolvimento, agora, o mercado global torna-se a instância capaz de conduzir ao crescimento sustentado.

O Relatório Brundtland vem cumprir, neste momento histórico, a função de, diplomaticamente, construir um terreno comum por onde possa surgir uma política de consenso capaz de dissolver as diferentes visões e interesses de países, povos e classes sociais. Embora reconhecendo que a pobreza e as disparidades sociais e econômicas devem ter tratamento prioritário, articulando-se com as ações de proteção ambiental, este relatório adota um tom diplomático, evitando tocar nas questões de fundo que envolvem as relações homem/sociedade/natureza nas relações de poder internacionais. O conceito oficial do desenvolvimento sustentável, adotado por vários governos, políticos, empresários e mesmo algumas ONGs, traz consigo a continuidade do processo de homogeneização cultural e ecológica, que, hoje, mais do que nunca, é comandada pelo capital transnacional. Para eles, não há contradições entre o processo de acumulação capitalista e a perspectiva de sustentabilidade. (GUZMÁN \& MIELGO, 1994)

Entretanto, este esforço consensual não conseguiu diluir os interesses diferentes em jogo, que se relacionam com as diferentes visões de mundo, em especial aquelas que, de uma forma ou de outra, não sucumbiram inteiramente à forma ocidental/moderna de pensar. Aí, as contradições e os dissensos na discussão da sustentabilidade vem à tona. Afinal, trata-se de definir o que e a quem se quer realmente sustentar. 


\section{4 - PARA UMA RESIGNIFICAÇÃO DO DESENVOLVIMENTO REGIONAL}

O planejamento regional, tomado na perspectiva multidimensional, incorporando a variável ambiental, coloca-se na base de um desejável processo de ajustamento do significado contemporâneo de desenvolvimento, sendo meta assegurar sua qualidade de sustentável. Portanto, é um planejamento estratégico como observa LEFF (1994): “o saber ambiental é uma consciência crítica e um propósito estratégico.”

Assume-se como pressuposto, portanto, que um planejamento regional (estratégico) tome como categoria analítica as necessidades humanas e históricas de uma dada sociedade, isto é, o seu o desenvolvimento além do meramente econômico, tendo como princípio, a justiça social; o que é passível de ser alcançado por meio de formas de organização sócio-espacial que ensejam articulações ambientalmente sustentáveis, nas quais figuram, como protagonistas privilegiados, os diversos agentes regionais partícipes dos processos de decisão e deliberação, introduzindo nexos de autonomia e vínculos de solidariedade.

Mas qual o significado da autonomia vista pela ótica do desenvolvimento humano regional sustentável? Para tentar uma aproximação com a questão, toma-se, como referência, o próprio significado etimológico da palavra autonomia e de suas derivações anomia e heteronomia. O sufixo nomia presente nos termos autonomia, anomia e heteronomia vem do grego nomos, e significa regra. Então, ao tomar o termo anomia, a presença do prefixo a (negação), refere-se a um estado de ausência de regras. Por exemplo, uma comunidade ou região que não sabe o que deve ou não ser feito para alcançar o seu desenvolvimento. Há aí uma ausência de princípios que deixam de motivar certos espaços regionais a perceber seus próprios elos. Há uma "deriva” (anomia) das comunidades regionais em traçar metas de desenvolvimento ou alcançá-las. Ao contrário, o prefixo hetero significa vários, conduzindo à compreensão de heteronomia como um estado de Cadernos do Leste Artigos Cientificos 
numerosas e variadas regras. No entanto, sua origem e definição são determinadas por outros grupos de interesse. Nesse estágio, o desenvolvimento regional, pode ser objeto de variadas concepções. Daí, resulta um certo encolhimento das comunidades locais e ou regionais, as quais passam agir por interesses próprios ou inclinações pessoais, faltando a interação com o outro, a noção de princípios coletivos, tais como, a cooperação, a solidariedade, a justiça, entre outros.

Durante um processo de desenvolvimento regional que tome como referência o desenvolvimento humano, o sujeito possível da autonomia, necessariamente, irá passar pela heteronomia, construindo pela experiência sua autonomia, à medida que descobre a importância do outro e das regras sociais (de justiça, de solidariedade-reciprocidade, de cooperação), o que resultará numa autonomia progressiva sobre a heteronomia. O poder autônomo corresponderá, portanto, à habilidade humana de não agir apenas por si, mas de acordo, em uníssono com outros. A autonomia, jamais, pertencerá, então, a um único sujeito; será parte de um grupo e apenas existirá enquanto o grupo se mantiver coeso. Inscreve-se, então, de maneira particular, a ideia de autonomia como centro da discussão para uma ressignificação do desenvolvimento regional, sobretudo de regiões pobres.

Entretanto, conquanto seja necessária a inserção da autonomia nos planos de desenvolvimento regional e/ou programas de governos, ainda são incipientes suas formas de operacionalização. Daí, certamente, a necessidade de se criar instrumentos que viabilizem a autonomia das comunidades (urbanas e rurais) e regiões, tendo-se em vista um desenvolvimento mais harmonioso para uma ressignificação do próprio desenvolvimento, considerando, por exemplo:

$>$ A busca de soluções locais adaptadas cultural e ecologicamente (o local e o regional como referência fundamental), articuladas com uma consciência aguda sobre as questões globais que rebatem no local;

Cadernos do Leste

Artigos Cientificos

Belo Horizonte, Edição Especial, 2000 a 2008 
Uma ética planetária e solidariedade transgeracional, restringindo o consumo perdulário dos recursos naturais;

A subordinação da economia a valores éticos e a objetivos sociais prioritários daí advindos;

A busca de novos paradigmas na ciência e na cultura, que possam respaldar os princípios acima listados e superar tanto o antropocentrismo como o biocentrismo, quanto os valores da modernidade capitalista, construindo uma nova relação homem/sociedade/natureza.

Entretanto, todos estes princípios não têm sentido, se não partirem da base (em geral excluída) da sociedade, de seus valores e anseios, mas, também, sem negar o papel regulador do Estado - que deve se reformular, buscando democraticamente um diálogo mais intenso nos marcos de uma ação articulada com a sociedade civil.

É possível dentro das argumentações traçadas até aqui, vislumbrar para regiões e localidades pobres as bases para um desenvolvimento urbano-rural regional sustentado, alicerçado em novas formas de manejo e modo de vida sustentável, isto é, aquele que “aponta de forma clara, para a necessidade de considerar, além do quesito produtividade, enfatizado no passado, outros indicadores, como a estabilidade e a sustentabilidade da produção, assim como a equidade social na avaliação dos processos de desenvolvimento [...].” (KITAMURA, 1994)

É desejável que projetos sustentáveis de desenvolvimento considerem o modelo de organização das comunidades regionais:

"A ideia de engajamento cívico, fundado nas experiências históricas, soma-se à da participação dos atores envolvidos no processo de criação de uma agricultura sustentável e, portanto, de gestão. É basicamente esta ideia de gestão, no contexto descentralizador que estamos vivendo, que abre a realidade para uma outra importante ideia de nosso tema: a região. Atualmente, a região não se define mais tão-somente pela

Cadernos do Leste

Artigos Cientificos

Belo Horizonte, Edição Especial, 2000 a 2008 
contiguidade física de suas atividades econômicas e instituições singulares, mas fundamentalmente, pela gestão das transformações econômicas, tecnológicas, ambientais e institucionais associadas à dinâmica da vida regionl. Implícito aí está o juízo de que, regionalmente, os atores podem exercer um maior controle do processo de desenvolvimento e, portanto, seriam menores os custos sociais de transação. Nesse sentido, regionalização é a territorialização da gestão de um plano de desenvolvimento." (MÜLLER, 1997)

CONWAY \& BARBIER (1988) salientam que uma agricultura sustentável vinculase intimamente às características intrínsecas do sistema regional, à natureza e intensidades de estresses físico-agrários (erosão, salinidade dos solos, escassez de umidade, entre outros), bem como à ação antrópica estrito senso. Aqui, a coerência ecológica no uso dos recursos naturais segundo a sua aptidão, associada à autonomia dos agricultores na estruturação social de suas próprias decisões, é, talvez, um caminho profícuo em direção a um desenvolvimento rural sustentável que assuma o meio ambiente, indissociado da melhoria do bem-estar social, como fundamento dos processos de organização regional e local.

Entretanto, vislumbrar o desenvolvimento sustentável rural numa dimensão da inclusão social, exige uma reflexão sobre as mudanças atuais no cenário mundial que impactam na produção rural. Em quase todo o mundo, a produção agropecuária insere-se em mercados extremamente competitivos, sujeitos, cada vez mais, a intensos processos de concentração, baseados nas economias de escala técnica dos grandes empreendimentos. São empreendimentos, em geral, voltados para produção de commodities, com requerimentos de grandes extensões de terra, portanto, favorecendo a concentração fundiária; e do uso intensivo de tecnologia e mecanização, em substituição a utilização de mão-de-obra. Estas atividades, de modo geral, são extremamente questionáveis do ponto de vista ambiental e, mesmo, do desenvolvimento humano de uma região.

Num outro extremo, têm-se a pequena produção autônoma, com toda a sua dificuldade de sobrevivência, cuja viabilidade, como fonte de subsistência familiar, é apenas uma alternativa no curto prazo. Se a ideia for buscar crescimento sustentável da renda e do 
bem-estar social numa perspectiva de longo prazo, há que se encontrar maneiras de orientar parcela desta produção para o mercado.

Conforme salienta SINGER (1998, p.131):

A fragilidade da produção autônoma reside em sua pequenez e isolamento. $\mathrm{O}$ fato de ela ser autônoma já implica dimensões reduzidas e inter-relacionamento apenas mediante intercâmbio no mercado. Este caráter da produção autônoma restringe brutalmente o acesso a tecnologias que exigem mais investimento e mais produção; ela exclui também a produção autônoma dos setores em que a mão invisível da gerência integra mais eficientemente atividades especializadas do que a mão invisível da concorrência no mercado."

Todas as restrições impostas à pequena produção autônoma reforçam a necessidade de se fortalecer a organização comunitária, nas palavras de POLÈSE (1998; p. 259-260):

"...reforzar las redes locales de interacción para promover acciones concertadas o proyectos de asociación entre gente de la región: gobiernos locales, empresas u otros actores. Las iniciativas de este tipo pueden tomar distintas formas, según el contexto u las institucines del país. Se habka tanbién de solidariedad, de sinergia o de redes de innovación, según las circustancias. Solidariedad, concertación, interación, comunidad, medio, todos esos términos nos llevan a una misma realidad: trabajar en grupo, com un espíritu de cooperación, constituye un activo. En princípio, la proximidad espacial favorece una concertación como ésta entre agentes económicos."

Todas estas ideias se materializam no que SINGER (1998) denominou de economia solidária, ou seja, uma forma de "organizar a produção em grande escala sem ser pelo molde capitalista [...]. A ideia é assegurar a cada um mercado para seus produtos e uma variedade de economias externa, de financiamento a orientação técnica, legal, contábil, etc., através da solidariedade entre produtores autônomos de todos os tamanhos." (SINGER, 1998, p. 131-132)

As denominadas redes de colaboração e solidariedade, as formas cooperativas de produção, consumo e financiamentos, enfim, a organização e a iniciativa comunitária contribuem para reforçar a sinergia do meio, ultrapassando sua dimensão econômica, e 
possibilitando criar no território um conjunto de valores próprios, uma identidade e cultura regional.

\section{5 - CONSIDERAÇÕES FINAIS}

Fica claro, pelo até aqui exposto, que há no seio da sociedade um intenso debate e uma disputa conceitual/ideológica sobre o conceito e os princípios do desenvolvimento sustentável. É uma discussão longe de estar resolvida (se é que é possível resolvê-la).

Convém recordar que, após a segunda guerra mundial até os dias atuais, pode-se identificar pelo menos três níveis conceituais relativos à ideia de desenvolvimento. O primeiro, que se tornou clássico, assevera que o desenvolvimento desejável é o econômico, no qual o progresso e o crescimento seriam os balizadores desse desenvolvimento. Em face da dinâmica capitalista, poderia ser alcançado, por meio de inovações tecnológicas, de avanços setoriais da economia, da organização hierarquizada e interdependente da estrutura produtiva (com a evidente difusão de assimetrias no nível das taxas de formação de capital). O crescimento econômico, importante referencial desse processo, passa a ser um fenômeno cíclico de duração variável, sujeito a oscilações conjunturais e estruturais. Portanto, a lógica do desenvolvimento e/ou das desigualdades regionais, nesse caso, é a lógica da expansão capitalista.

O segundo nível de discussão sobre o desenvolvimento vem acoplado ao debate dos problemas ambientais em âmbito mundial, os quais encontraram grande divulgação nos anos 70 e 80 . Inaugurava-se uma nova fase de mudança nos fóruns de discussão temática, abrangendo esferas governamentais e não governamentais, relações internacionais, instituições acadêmicas preocupadas com a "economia" ambiental, momento em que houve uma ampla inserção da mídia internacional no debate. 
Paralelamente, no Brasil, a questão ambiental reunia diversos adeptos na sociedade civil, com o surgimento de diversas organizações sociais e político-partidárias, a exemplo de: partidos políticos voltados à causa ecológica; ecobusiness (associados à indústria despoluidora); organizações não-governamentais (ONGs), nacionais e internacionais; firmas e instituições de prestação de serviços, consultoria técnica, promoção de campanhas, eventos educacionais e ativismo ecológico; entidades religiosas (Comissão Pastoral da Terra - CPT, trabalhando no nível da conscientização e denúncia).

Segundo ZUCKERMAN (1992), a título de exemplo, resultaram da " Rio/92, novos lastros de inquietação no que diz respeito a questões não resolvidas: interesses nacionais conflitantes; diferenças nos problemas ambientais nacionais e globais; questões de curto e de longo prazo não pertencerem à mesma categoria; o desenvolvimento dos países inevitavelmente deflagraram novos problemas ambientais.”

No final da década de 80, define-se a terceira fase da discussão e debate sobre meio ambiente e desenvolvimento local-regional. Adota-se a proposta-síntese do chamado desenvolvimento sustentável - sustainable development. (RELATÓRIO BRUNDTLAND, 1987). A sua receptividade preconiza, na atualidade, um perfil conciliador que se torna símbolo de um consenso ideal.

Sachs afirma que a noção política de desenvolvimento sustentável do Relatório Brundtland incorpora a ideia de eco desenvolvimento : "o indissolúvel elo em duas direções entre desenvolvimento e meio ambiente é o resultante conceito normativo de eco desenvolvimento, mais tarde renomeado como desenvolvimento sustentável." (CONFERÊNCIA DE ESTOCOLMO, 1972)

O paradigma "ecológico social", como vem sendo denominado, embora ainda não hegemônico, está emergindo como dominante em detrimento do paradigma tecnológico social: "Organismos internacionais de fomento cooptaram-no e exigem que medidas com ele compatíveis constem nos projetos submetidos a suas carteiras de financiamentos..” (LÉLÉ,1991)

Cadernos do Leste

Artigos Cientificos

Belo Horizonte, Edição Especial, 2000 a 2008 
A diversidade de atores sociais, interesses, visões de mundo e projetos de sociedade conformam uma diversidade no pensar e propor a reorientação dos ideais de desenvolvimento.

Finalmente, cabe enfatizar que as abordagens mais profundas e consistentes do desenvolvimento sustentável se arranjam em torno de valores/princípios fundamentais que devem ser destacados:

> Fortalecimento da democracia participativa - a ampliação do exercício da cidadania para a participação social;

Busca da inclusão, da equidade e da solidariedade social;

Respeito e promoção da pluralidade cultural, das identidades étnicas e dos saberes tradicionais e uma nova articulação (horizontal) destes saberes com o conhecimento científico ocidental;

Reforço à autonomia, autodeterminação e autogestão das comunidades sobre seus recursos produtivos e formas de vida;

Atenção às especificidades dos ecossistemas (e o conhecimento profundo de suas dinâmicas), valorização de seus processos e potenciais ecológicos e de sua biodiversidade, assim como a observação de sua capacidade de suporte. 


\section{REFERÊNCIAS BIBLIOGRÁFICAS}

ACSELRAD, H. Desenvolvimento sustentável; a luta por um conceito. R. Proposta. Rio de Janeiro, n. 56, p. 5-8, 1993.1 v.

Sustentabilidade e território nas Ciências Sociais. In: ENCONTRO NACIONAL ANPUR. Novos recortes territoriais, novos sujeitos sociais; desafios ao planejamento, 7, Recife, 1997. Anais. Recife: ANPUR, 1997. v. 3.

ARANHA, M. L. A. ; MARTINS, M. H. P. O problema do crescimento. In: ARANHA, M. L. A. Filosofando; introdução à filosofia. São Paulo: Moderna, 1986. p. 165-171.

ALMEIDA, J. Projetos de autonomia na agricultura; novas concepções para o social. R. Economia e Sociologia Rural, v. 34, n. 3-4, s. p., s. d.

BARBIER, E. The concept of sustainable economic development. Environmental Conservation, s. d: v. 14, n. 2, 1987.

BRÜSEKE, F. J. O problema do desenvolvimento sustentável. In: CAVALCANTI, C., org. Desenvolvimento e natureza; estudos para uma sociedade sustentável. São Paulo: Cortez, 1995. p. $29-40$.

BUARQUE, C. A revolução nas prioridades; da modernidade técnica à modernidade ética. São Paulo: Paz e Terra, 1994. 1v.

CAPRA, F. O ponto da mutação. São Paulo: Cultrix, 1982. 1 v.

COLBY,M. Environmental management in development; the evolution of pardigms. s. d. World Bank, 1990. (Discussion paper, 80).

COSTA, H. S. M. Questão ambiental, população e espaço urbano: em busca de um n ovo paradigma? In: ENCONTRO NACIONAL DE ESTUDOS POPULACIONAIS, 8, Brasília, 1992. Anais. Brasília: ABEP, 1992. p. 11-26.

COSTA, J. M. M. Reestruturação, desenvolvimento sustentável e desenvolvimento econômico. Cadernos IPPUR/UFRJ, Rio de Janeiro, v. 8, n. 2-3, p. 41-62, set./dez. 1994.

DALY, H.E. A economia ecológica e o desenvolvimento sustentável. Rio de Janeiro: ASPTA, 1991. 1 v. (Texto para debate, 34).

DIEGUES, A. C.S. O mito moderno da natureza intocada. São Paulo: Hucitec, 1996. 1 v.

EVASO, A. S. et. al. Desenvolvimento sustentável; mito ou realidade? In: Geografia, política e cidadania. São Paulo: AGB, 1996. p. 91-100. (Terra Livre, 11/12). 
FERREIRA, L. C. A política ambiental no Brasil. In: MARTINE, G., org. População e meio ambiente; verdades e contradições. Campinas: UNICAMP, 1993. 1 v.

. ; VIOLA, E., org. Incertezas de sustentabilidade na globalização. Campinas: UNICAMP, 1996. $1 \mathrm{v}$.

GERTEL, S. O espaço do desenvolvimento; o planejamento estratégico para a sustentabilidade de seres humanos. R. do Departamento de Geografia da USP. São Paulo, n. 8, s. d. 1994.

GONÇALVES, C. V. P. Os (des)caminhos do meio ambiente. São Paulo: Contexto, 1989. 1 v.

Formação sócio-espacial e questão ambiental no Brasil. In: BECKER, B. ; CHRISTOFOLETTI, A ; DAVIDOVICH, F. R. ; GEIGER, P. P., org. Geografia e meio ambiente no Brasil. São Paulo: Hucitec, 1995. P. 309-333.

GOODMAN, D. ; REDCLIFT, M. Environment and development in Latin America; politics of sustainability. Manchester: Manchester University Press, $1991.1 \mathrm{v}$.

GUIMARÃES, R. P. The ecoploitics of development in the third world. London: Lynne Rienner Publishers, 1991. $1 \mathrm{v}$.

GUZMÁN, E. S.; MIELGO, A M.A. Para una teoría etnoecológica centro-periferia desde la agroecologia. In: Prácticas ecológicas para una agricultura de calidad. Toledo: s. ed. 1994. p. 448460.

HARVEY, David. A condição pós-moderna. São Paulo: Loyola, 1993. 1 v.

HIERNAUX, D. ; LINDÓN, A. En qué sentido las desigualdades regionales? R. Eure, Santiago do Chile, v. 22, n. 68, p. 29-43, 1997.

HOGAN, D. População e meio ambiente. Campinas: UNICAMP, 1992. 1 v.

. ; VIEIRA, P. , org. Dilemas sócio-ambientais e desenvolvimento sustentável. Campinas: UNICAMP, 1992. $1 \mathrm{v}$.

IZARD, Walter. Gravity, potencial and epatial $\mathrm{u}=$ intercion model . In: Methods of regional analysis; na introducino to regional science. Cambridge: MIT, 1960. cap. 11, p. 493-568.

KITAMURA, P. C. A agricultura e o desenvolvimento sustentável. Agricultura Sustentável, s. n. t. jan./abr. 1994.

KOPPENBURG JÚNIOR, J. Social theory and the de/reconstruction of agricultural science: local knowledge for an alternative agriculture. Rural Sociology, s. 1., v. 56, n. 4, p. 519-548. 1991.

LEFF, E. Ecologia y capital; racionalidad ambiental, democracia participativa y desarrollo sustentable. Madri: Siglo Veintiuno de España, 1994. 1 v. 
Ignacy Sachs el ecodesarrollo. s. n. t. , 1997. 10 p. (Texto avulso).

La insuportable levedad de la globalización; la capitalización de la naturaleza y las estrategias fatales de sustentabilidad. R. Universidad de Guadalajara, Guadalajara, n. 6, s. p., 1996.

MÜLLER, G. Economia política e ecologia; instituições e redes de compromissos cívicos numa agricultura. R. de Geografia, São Paulo, s. n., p. 49-78, 1997.

OLIVEIRA, F. A economia da dependência imperfeita. Rio de Janeiro: Graal, 1977. 1 v.

PÁDUA, J. Espaço público, interesses privados e política ambiental. São Paulo em Perspectiva, São Paulo, v. 3, n. 4, p. 2-4, 1989.

PAULA, J. A . , ed. Biodiversidadde, população e economia; uma região de Mata Atlântica. Belo Horizonte: UFMG/CEDEPLAR/ECMVS, 1997. 1 v.

PENTEADO, H. D. Meio ambiente e formação de professores. São Paulo: Cortes, 1994. 1 v.

PERPÉTUO, G. R. O .Homem x natureza; origens e transformações da concepção ocidental. Belo Horizonte: s. ed., 1994. 91 p. Monografia de Graduação em Ciências Sociais/UFMG.

POLĖSE, Mario. Economia urbana y regional; introducción a la relación entre territorio y desarrollo. Cartago: Libro Universitario Regional, 1998. 1 v.

R. JÚNIOR, J. O que é positivismo. São Paulo: Brasiliense, 1991. 1 v.

RAMPAZZO, S. E. A questão ambiental no contexto do desenvolvimento econômico. Perspectiva, Erechim, v. 20, n. 72, p. 19-43, 1996.

RAYNAUT, C. O desenvolvimento e as lógicas da mudança; a necessidade de uma abordagem holística. Cadernos de Desenvolvimento e Meio Ambiente, Curitiba: UFPR, p. 81-100. s. d.

SACHS, I. Ecodesenvolvimento; crescer sem destruir. São Paulo: Vértice, 1986. 1 v.

Estratégias de transição para o século XXI. In: BURSZTYN, M. Para pensar o desenvolvimento sustentável. São Paulo: Brasiliense, 1993. 1 v.

SANTOS, B. S. Um discurso para as ciências. Porto: Afrontamento, 1987. 1 v.

SILVA, C. E. M. Geografia; modernidadde, pós-modernidade e transdiciplinaridade. Belo Horizonte: s. ed., 1996.9 p. Texto avulso.

Avulso.

- Para chegar à sustentabilidade. Belo Horizonte: s. ed., 1996, 17. P. Texto

SINGER, Paul. Globalização e desemprego; diagnóstico e alternativas. São Paulo,:Contexto, s. d. $1 \mathrm{v}$. 
SOARES, L. H. P. Gestão ambiental, questão social, questão de estado. São Paulo em Perspectiva, São Paulo, v. 6, n. 1-2, p. 73-75, 1992.

STAHEL, A . W. Capitalismo e entropia; os aspectos ideológicos de uma contradição e a busca de alternativas sustentáveis. In: CAVACANTI, C. , org. Desenvolvimento e natureza; estudos para uma sociedade sustentável. São Paulo: Cortez, p. 104-127, 1995.

VIOLA, E. ; LEIS, V. A evolução das políticas ambientais no Brasil, 1971-1991: do bissetorialismo preservacionista para o multissetorialismo orientado para o desenvolvimento sustentável. In: HOGAN, D. ; VIEIRA, P. , org. Dilemas sócio-ambientais e desenvolvimento sustentável. Campinas: UNICAMP, 1992. 1 v. Bibliografia. 